\title{
Post-mortem findings in southern right whales Eubalaena australis at Península Valdés, Argentina, 2003-2012
}

\author{
Denise McAloose ${ }^{1,2, *}$, M. Virginia Rago ${ }^{2,3}$, Matías Di Martino ${ }^{2,3}$, Andrea Chirife ${ }^{2}$, \\ Sarah H. Olson ${ }^{3}$, Lucas Beltramino ${ }^{2}$, Luciana M. Pozzi ${ }^{2,4,5}$, Luciana Musmeci ${ }^{2,4,5}$, \\ Luciano La Sala ${ }^{2,6}$, Nadia Mohamed ${ }^{2}$, Juan Emilio Sala ${ }^{2}$, Lucas Bandieri ${ }^{2}$, \\ Julian Andrejuk ${ }^{2}$, Ania Tomaszewicz ${ }^{1}$, Tracie Seimon ${ }^{1}$, Mariano Sironi ${ }^{2,7}$, \\ Luis E. Samartino ${ }^{8}$, Victoria Rowntree ${ }^{2,9}$, Marcela M. Uhart ${ }^{2,3,10}$ \\ ${ }^{1}$ Wildlife Conservation Society Zoological Health Program, Bronx, New York 10464, USA \\ ${ }^{2}$ Southern Right Whale Health Monitoring Program, Los Alerces 3376, Puerto Madryn, Chubut 9120, Argentina \\ ${ }^{3}$ Wildlife Conservation Society Wildlife Health \& Health Policy Program, Bronx, New York 10464, USA \\ ${ }^{4}$ CENPAT-CONICET, Puerto Madryn, Chubut 9120, Argentina \\ ${ }^{5}$ Fundación Patagonia Natural, Puerto Madryn, Chubut 9120, Argentina \\ ${ }^{6}$ CONICET- Universidad Nacional del Sur, Bahía Blanca, Buenos Aires 8000, Argentina \\ ${ }^{7}$ Instituto de Conservación de Ballenas, Buenos Aires 1429, Argentina \\ ${ }^{8}$ Instituto Patobiologa INTA, Hurlingham, Buenos Aires 1686, Argentina \\ ${ }^{9}$ Department of Biology, University of Utah, Salt Lake City, Utah 84112, USA \\ ${ }^{10}$ One Health Institute, School of Veterinary Medicine, University of California, Davis, California 95616, USA
}

\begin{abstract}
Between 2003 and 2012, 605 southern right whales (SRW; Eubalaena australis) were found dead along the shores of Península Valdés (PV), Argentina. These deaths included alarmingly high annual losses between 2007 and 2012, a peak number of deaths (116) in 2012, and a significant number of deaths across years in calves-of-the-year (544 of 605 [89.9\%]; average $=60.4 \mathrm{yr}^{-1}$ ). Postmortem examination and pathogen testing were performed on 212 whales; 208 (98.1\%) were calvesof-the-year and $48.0 \%$ of these were newborns or neonates. A known or probable cause of death was established in only a small number $(6.6 \%)$ of cases. These included ship strike in a juvenile and blunt trauma or lacerations $(n=5)$, pneumonia $(n=4)$, myocarditis $(n=2)$, meningitis $(n=1)$, or myocarditis and meningitis $(\mathrm{n}=1)$ in calves. Ante-mortem gull parasitism was the most common gross finding. It was associated with systemic disease in a single 1-2 mo old calf. Immunohistochemical labeling for canine distemper virus, Toxoplasma gondii and Brucella spp., and PCR for cetacean morbillivirus $(\mathrm{CeMV})$, influenza $\mathrm{A}$, and apicomplexan protozoa were negative on formalin-fixed, paraffinembedded lung and brain samples from a subset of whales; PCR for Brucella spp. was positive in a newborn/neonate with pneumonia. Skin samples from whales with gull parasitism were PCR negative for CeMV, poxvirus, and papillomavirus. This is the first long-term study to investigate and summarize notable post-mortem findings in the PV SRW population. Consistent, significant findings within or between years to explain the majority of deaths and those in high-mortality years remain to be identified.
\end{abstract}

KEY WORDS: Argentina $\cdot$ Calf $\cdot$ Eubalaena australis $\cdot$ Histology $\cdot$ Mortality $\cdot$ Neonate $\cdot$ Península Valdés $\cdot$ Southern right whale

\section{INTRODUCTION}

The southern right whale (SRW; Eubalaena australis), one of the 3 baleen whale species in the genus

*Corresponding author: dmcaloose@wcs.org
Eubalaena, was hunted to near extinction in the late $19^{\text {th }}$ to early $20^{\text {th }}$ centuries. Since the enactment of harvesting bans in 1935, SRW populations have been slowly recovering (IWC 2001, 2011). Known breed- 
ing and calving sites occur off the coasts of Brazil, Argentina, Tristan da Cunha, West, South and East Africa, Australia, and New Zealand (Payne 1986, IWC 2001). Each year a portion of the South Atlantic population migrates to the calm waters off Península Valdés (PV) in Patagonia, Argentina, to mate, give birth, and nurse their calves over the austral winter (Payne 1986, IWC 2001, 2011, 2014, Sironi 2004). Many aspects of SRW ecology, including population dynamics, behavior, sound production/vocalization, and aspects of reproduction, calving, and calf rearing, have been continuously or periodically studied at PV since the early 1970s (Cummings et al. 1972, Payne et al. 1983, Thomas \& Taber 1984, Payne 1986, Best \& Ruther 1992, Best \& Schell 1996, Rowntree et al. 1998, 2001, Cooke et al. 2001, Leaper et al. 2006, Valenzuela et al. 2009). More recently, with the establishment in 2003 of the Southern Right Whale Health Monitoring Program (SRWHMP), investigations to understand SRW health and causes of mortality have also been pursued (Uhart et al. 2008, 2009, La Sala et al. 2012, Martino et al. 2012, Rosas et al. 2012, Rowntree et al. 2013, Sironi et al. 2014, Marón et al. 2015, Torres et al. 2015, Wilson et al. 2015).

Based on historical data, the mortality rate of SRWs at PV prior to 2002 appeared to mirror the population's $6.9 \%$ annual growth rate (Cooke et al. 2001, Cooke 2012, Rowntree et al. 2013). However, from 2003 to 2012, we recorded 605 SRW deaths at PV. Over this time period, the total number of deaths was much higher than that of the 3 previous decades combined (Rowntree et al. 2013), average annual deaths were significantly elevated relative to those in the previous decade (over 50 versus 8.2) (Rowntree et al. 2013, Marón et al. 2015), and there was an unprecedented number of deaths in calves-of-theyear (462/496, 93.1\%) from 2007 to 2012. In 2012, 116 SRW deaths were recorded; 113 were calves-of-theyear (Rowntree et al. 2013). This was the highest number of recorded natural mortalities and the highest number of calf deaths for the species in a single year, and losses in this year alone were estimated to represent nearly $3 \%$ of the South Atlantic SRW stock (Rowntree et al. 2013). Current estimates are that deaths between 2003 and 2012 are responsible for a reduction in the SRW population growth rate from $6.9 \%(1971-2000)$ to $5.1 \%$ (2000-2010) (Cooke 2012, Rowntree et al. 2013). Increased mortality monitoring over the past decade does not explain the pattern or scale of deaths (Rowntree et al. 2013), and similar die-offs have not been reported in other South Atlantic right whale calving areas (Best et al. 2001, Greig et al. 2001) or in other mysticete populations.
Additionally, while there is some evidence that density-dependent processes could be limiting PV SRW population growth (IWC 2014), it is unlikely to be the only factor given the unusually high number of calf deaths relative to those in other age classes.

Descriptions of health surveillance or investigations into the causes of individual animal death or large-scale mortality events in whales, including those for SRWs, are limited (Stroud \& Roffe 1979, Dailey et al. 2000, Best et al. 2001, Knowlton \& Kraus 2001, Greig et al. 2001, Gulland et al. 2005, Moore et al. 2005, Borsa 2006, Panigada et al. 2006, Campbell-Malone et al. 2008, Bogomolni et al. 2010, Cassoff et al. 2011, Groch et al. 2012, Martino et al. 2012, Rosas et al. 2012, Arbelo et al. 2013, Herráez et al. 2013, Rowntree et al. 2013, Marón et al. 2015). These include ship strike and entanglement in fishing gear as a commonly documented cause of mortality in the northern right whale (NRW; Eubalaena glacialis) (Knowlton \& Kraus 2001, Campbell-Malone et al. 2008, Cassoff et al. 2011), sonar as the cause of mass strandings of Cuvier's (Ziphius cavirostris), Blainville's (Mesoplodon densirostris) and Gervais' beaked whales (Mesoplodon europaeus) (Arbelo et al. 2013), and suspicion of biotoxicity due to harmful algal blooms or malnutrition in humpback (Megaptera novaeangliae) and gray (Eschrichtius robustus) whales, respectively (Geraci et al. 1989, Gulland et al. 2005).

In this paper, we summarize post-mortem findings in SRWs that died from 2003 through 2012 along the coast of PV, Argentina. We also discuss several factors, including trauma, infectious disease, and complications of gull-inflicted skin wounds (a form of ante-mortem parasitism by kelp gulls Larus dominicanus (Thomas 1988, Rowntree et al. 1998, Sironi et al. 2009, Marón et al. 2015), independently and in the context of age, in the deaths of these whales.

\section{MATERIALS AND METHODS}

\section{Gross necropsy, histology, and immunohistochemical labeling}

External examination with collection of morphometric data, gross necropsy examination, tissue sample collection for histology and ancillary diagnostics, and photographic documentation were performed by the SRWHMP on 212 of 605 SRWs that were either found dead or that stranded alive and subsequently died along the coast of PV between June 22, 2003 and November 15, 2012. Gross necropsy examination 
was performed using a right whale necropsy protocol developed by the SRWHMP (A. Chirife unpubl. data) based on the methods of McLellan et al. (2004), F. Gulland (pers. comm.), A. Carribero (unpubl. data), and Geraci \& Lounsbury (2005). Carcass condition code (decomposition) was graded subjectively on a scale from 1 to 5 ( 1 = alive when first reported/investigated, 2 = freshly dead, 3 = moderately decomposed but tissues largely intact, 4 = advanced decomposition, $5=$ mummified or skeletonized) (Geraci \& Lounsbury 2005). Age class and an estimation of calf age were performed using a combination of morphologic features, including body length (snout to fluke notch), appearance of the umbilicus (open, healing, healed), snout to blowhole length as a percentage of body length, the appearance of the blowhole and callosities, and presence or absence and color and location of cyamids (Table 1).

Tissue samples collected from dead whales were preserved in 10\% neutral buffered formalin and stored at room temperature. Soft tissues for histologic examination were processed using routine methods, embedded in paraffin blocks, sectioned at $5 \mu \mathrm{m}$, and stained with hematoxylin and eosin (HE). Bone samples for histology, all collected from the humerus, were decalcified (Polyscientific R\&D) then processed and stained using the same methods as for soft tissues.

Immunohistochemical (IHC) assays for canine distemper virus (CDV) antigen with proven cross-reactivity to cetacean morbillivirus (CeMV) (Stone et al. 2011) and Toxoplasma gondii antigen were performed (Athens Veterinary Diagnostic Laboratory Histology Section, The University of Georgia, Athens, GA, USA) on formalin-fixed, paraffin embedded (FFPE) SRW lung $(\mathrm{n}=10)$ and brain samples $(\mathrm{n}=11)$. IHC for Brucella spp. was performed (National Veterinary Services Laboratories, Ames, IA, USA) on the same group of lung samples and on a neonatal whale with meningitis. CDV IHC used a monoclonal antibody targeting the CDV nucleoprotein (CDV-NP; VMRD) and positive and negative controls as previously described by Stone et al. (2011). IHC for T. gondii used goat polyclonal anti- T. gondii (PABTOXO; VMRD) as the primary antibody and a biotinylated anti-goat IgG antibody (BA-5000; Vector Labs) as the secondary antibody. IHC for Brucella

Table 1. Eubalaena australis. Morphologic features used in assigning southern right whale age classes and estimating age. Body length: straight length from snout to fluke notch (small calves: $<5.4 \mathrm{~m}$; medium calves: 5.5-6.4 m; large calves: >6.5 m); snout to blowhole: straight length of snout to blowhole distance as a percentage of straight body length.

\begin{tabular}{|c|c|c|c|c|c|}
\hline $\begin{array}{l}\text { Age class and } \\
\text { estimated age }\end{array}$ & $\begin{array}{l}\text { Body } \\
\text { length }(\mathrm{m})\end{array}$ & Umbilicus & $\begin{array}{l}\text { Snout to blowhole } \\
\text { (\% body length) }\end{array}$ & $\begin{array}{l}\text { Morphologic } \\
\text { features }\end{array}$ & Cyamids \\
\hline $\begin{array}{l}\text { Fetus } \\
(\leq 0 \mathrm{~d})\end{array}$ & $<5$ & Open & $<16$ & $\begin{array}{l}\text { Lung sinks } \\
\text { Smooth callosities }\end{array}$ & None \\
\hline $\begin{array}{l}\text { Calf } \\
\text { Newborn } \\
(1 \mathrm{~d})\end{array}$ & $<5$ & Open & $15-16$ & $\begin{array}{l}\text { Lung floats } \\
\text { Rounded rostral islands w/central sensory hair } \\
\text { High rounded blowhole region } \\
\text { Upturned rostrum } \\
\text { Smooth callosities }\end{array}$ & None \\
\hline $\begin{array}{l}\text { Newborn-neonate } \\
(1 \mathrm{~d}-2 \mathrm{wk})^{\mathrm{a}}\end{array}$ & $<5$ & Not visible & $15-16$ & $\begin{array}{l}\text { Lung floats } \\
\text { Rounded rostral islands w/central sensory hair } \\
\text { High rounded blowhole region } \\
\text { Upturned rostrum } \\
\text { Smooth callosities }\end{array}$ & $\begin{array}{l}\text { Orange (few) } \\
\text { On cheeks }\end{array}$ \\
\hline $\begin{array}{l}\text { Neonate } \\
(<2 \mathrm{wk})\end{array}$ & $<5$ & Healing & $15-16$ & $\begin{array}{l}\text { Lung floats } \\
\text { Smooth callosities }\end{array}$ & $\begin{array}{l}\text { Orange (few) } \\
\text { On cheeks }\end{array}$ \\
\hline $\begin{array}{l}\text { Young calf } \\
(1-2 \mathrm{mo})\end{array}$ & $5-7$ & Healed & $15-16$ & $\begin{array}{l}\text { Lung floats } \\
\text { Slightly roughened callosities }\end{array}$ & $\begin{array}{l}\text { Orange } \\
\text { On cheeks }\end{array}$ \\
\hline $\begin{array}{l}\text { Old calf } \\
(4-6 \mathrm{mo})\end{array}$ & $7-9$ & Healed & $15-16$ & $\begin{array}{l}\text { Lung floats } \\
\text { Roughened callosities }\end{array}$ & $\begin{array}{l}\text { White } \\
\text { On callosities }\end{array}$ \\
\hline $\begin{array}{l}\text { Juvenile } \\
\qquad(6 \mathrm{mo}-5 \mathrm{yr})\end{array}$ & $9-12$ & Healed & $17-19$ & $\begin{array}{l}\text { Lung floats } \\
\text { Roughened callosities }\end{array}$ & $\begin{array}{l}\text { White } \\
\text { On callosities }\end{array}$ \\
\hline $\begin{array}{l}\text { Adult } \\
(>5 \mathrm{yr})\end{array}$ & $>12$ & Healed & $>20$ & $\begin{array}{l}\text { Lung floats } \\
\text { Roughened callosities }\end{array}$ & $\begin{array}{l}\text { White } \\
\text { On callosities }\end{array}$ \\
\hline
\end{tabular}


spp. was performed using 2 rabbit-derived polyclonal antibodies developed against killed, whole-cell Brucella abortus and B. ovis (antibodies provided by Dr. Steven Olsen, National Animal Disease Center, Ames, IA, USA).

Because many of the whale samples had been stored in formalin for several weeks to a year prior to histologic processing and due to concerns about tissue and antigen degradation from autolysis or complications of prolonged formalin fixation, IHC for Factor VIII was run as an internal positive control for brain samples and IHC for cytokeratins (AE1/ AE3) was run as an internal positive control for lung samples (Athens Veterinary Diagnostic Laboratory Histology Section, The University of Georgia, Athens, GA, USA). For Factor VIII labeling, rabbit polyclonal anti-Factor VIII (250A-18; Cell Marque) was the primary antibody and a biotinylated antirabbit IgG antibody (BA-1000; Vector Labs) was the secondary antibody. For AE1/AE3 IHC, a mouse monoclonal anti-cytokeratin cocktail (AE1/AE3; 313M18; Cell Marque) was the primary antibody and a biotinylated anti-mouse IgG antibody (BA-2001; Vector Labs) was the secondary antibody.

Heat-induced epitope retrieval (HK086-9K; Biogenex) for CDV, Factor VIII, and AE1/AE3, and protease 3 enzyme retrieval (760-2020; Ventana) for $T$. gondii, along with endogenous peroxidase quenching (342902; Fisher Scientific) and additional blocking (Power Block, HK085-5K; Biogenex), were included in sample processing for these assays. Antigen retrieval for the Brucella spp. assay used a pretreatment solution (Diva Decloaker; Biocare Medical) at $121^{\circ} \mathrm{C}$ for $10 \mathrm{~min}$ in a pressurized chamber and blocking with normal goat serum. Positive controls were FFPE CDV-positive domestic dog lung tissue, T. gondii-positive brain tissue from a wild turkey, B. abortus-positive tissue from a cow, normal domestic dog gingiva and tonsil for Factor VIII, and normal domestic dog skin for AE1/AE3. Purified mouse immunoglobulin in buffer $(\mathrm{NC} 494 \mathrm{H}$; Biocare Medical, LLC), purified goat immunoglobulin in buffer (HK406-5G; Biogenex), and purified rabbit immunoglobulin in buffer $\left(\mathrm{NC}_{4} 95 \mathrm{H}\right.$; Biocare Medical, LLC) was substituted for the primary antibody as a negative control in the CDV and AE1/AE3, $T$. gondii, and Factor VIII IHC assays, respectively. Negative control slides were stained without the primary antibody in the Brucella spp. assay. Brucella spp. IHC was performed using an automated IHC stainer and reagents system (Leica Bond-MAX ${ }^{\mathrm{TM}}$, Leica Biosystems). The remaining IHC assays utilized a streptavidin HRP (HP604H; Biocare Medical,
LLC), DAB chromagen (K3466; Dako) system after which tissue sections were counterstained, dehydrated, cleared, and cover-slipped. Certified pathologists performed examinations of all histologic sections and IHC interpretations of all tissues.

\section{Polymerase chain reaction (PCR)}

For PCR, DNA or RNA was extracted from a total of 45-50 $\mu \mathrm{m}$ scrolls of FFPE lung $(\mathrm{n}=10)$, brain $(\mathrm{n}=11)$, or skin $(\mathrm{n}=16)$ using a QIAamp DNA kit (papillomavirus, poxvirus, apicomplexa, glyceraldehyde 3phosphate dehydrogenase gene [GAPDH]) or a RNeasy FFPE kit (cetacean morbillivirus [CeMV], influenza A [IA], GAPDH) (Qiagen Inc.), or RecoverAll ${ }^{\mathrm{TM}}$ Total Nucleic Acid Isolation kit (Cat No. AM1975, Life Technologies) (Brucella spp. assay) per the manufacturer's protocols. Conventional PCR or reverse transcription (RT) PCR (CeMV and GAPDH) was performed targeting the P gene of CeMV, the L1 gene of papillomavirus, the DNA topoisomerase I and DNA polymerase genes of poxvirus, the 18S rRNA gene for apicomplexan protozoa, and the GAPDH gene (amplification control). Semi-quantitative real-time PCR for the 16S rRNA gene and outer membrane protein (OMP) 2 gene (confirmatory test for positive samples) of terrestrial and marine Brucella spp., and RT-PCR for the IA matrix gene were also performed. Primer sequences, assay targets, anticipated amplicon size, sensitivity, and references are listed in Table S1 in the Supplement at www.int-res.com/articles/suppl/ d119p017_supp.pdf. Amplitaq GOLD ${ }^{\circledR} 360$ master mix (Thermo Fisher Scientific) was used with DNA extracts in conventional PCR assays, and Qiagen's One-Step RT-PCR kit (Qiagen Inc.) was used in conventional RT-PCR assays with RNA extracts per the manufacturer's protocols. Final primer concentrations in PCR reactions were $1 \mu \mathrm{M}$ (conventional PCR assays), $2.0 \mu \mathrm{M}$ (papillomavirus assay), or $0.4 \mu \mathrm{M}$ (RTPCR). Visualization of results in conventional PCR assays was performed using SYBR ${ }^{\circledR}$ safe DNA gel stain (Thermo Fisher Scientific).

For CeMV and GAPDH RT-PCR, the cycling parameters were $50^{\circ} \mathrm{C}$ for $30 \mathrm{~min}, 95^{\circ} \mathrm{C}$ for $10 \mathrm{~min}$; 45 cycles of $95^{\circ} \mathrm{C}$ for $30 \mathrm{~s}, 55^{\circ} \mathrm{C}$ for $30 \mathrm{~s}$, and $72^{\circ} \mathrm{C}$ for $30 \mathrm{~s}$; and a final elongation step of $72^{\circ} \mathrm{C}$ for $5 \mathrm{~min}$. Primers were developed through alignment of conserved regions of available CeMV (AF333347, JN210891，HQ829972，HQ829973，FJ842381，AF20 0817, KF650727, AF014953, PCNPS) or GAPDH (XM_004284174，XM_004319930，XM_007165130, XM_007470992) sequences in GenBank (National 
Center for Biotechnology Information: www.ncbi. nlm.nih.gov/genbank/).

Quantitative RT-PCR for IA was performed using a modified protocol from Spackman et al. (2003). The following was added to the $25 \mu \mathrm{l}$ PCR reaction: $0.4 \mu \mathrm{M}$ of each primer, $0.2 \mu \mathrm{M}$ probe, $6.25 \mu \mathrm{l}$ TaqMan ${ }^{\circledR}$ Fast Virus 1 Step Master Mix (Life Technologies), $2.5 \mu \mathrm{l}$ of $10 \times$ exogenous internal positive control primers and probe, $0.5 \mu l$ of $50 \times$ exogenous internal positive control DNA (TaqMan ${ }^{\circledR}$ Exogenous Internal Positive Control kit, Life Technologies), and DNase/RNasefree water. The exogenous internal positive control reagents served as inhibition controls in the PCR reactions. A no-template negative control and positive controls (see below) were included in the testing. Samples were tested under the following cycling conditions: $50^{\circ} \mathrm{C}$ for $20 \mathrm{~min}, 95^{\circ} \mathrm{C}$ for $5 \mathrm{~min}$, followed by 45 cycles of $95^{\circ} \mathrm{C}$ for $15 \mathrm{~s}$ and $60^{\circ} \mathrm{C}$ for $30 \mathrm{~s}$.

Poxvirus PCR assays targeted the DNA topoisomerase I gene (Bracht et al. 2006) or a long (543 bp) (Bracht et al. 2006) or short (192 bp) region of the DNA polymerase gene. Degenerate primers targeting the short region of the DNA polymerase gene were developed from an alignment of the following poxviruses in GenBank: DQ377945 (vaccinia virus), JX878410 (monkey pox), HQ407377 (cowpox), NC 027213 (raccoon pox), AY780678 (pinniped pox), DQ202293 (harbor seal parapox), NC025963 (red deer parapox), AY386265 (bovine papular stomatitis virus), AY952942 (stellar sea lion parapox), NC00 4002 (sheepox), NC004003 (goat pox), JX565576 (myxoma virus), KC409043 (cetacean pox), AY46 3007 (dolphin pox), AY424955 (Stellar sea lion pox), AY841895 (deer pox), KF425535 (sea otter pox), NC005309 (canary pox), KC017893 (avipox), and NC024446 (penguin pox). Touchdown PCR was performed on a $192 \mathrm{bp}$ region of Pox DNA polymerase using the following cycling conditions: (1) $95^{\circ} \mathrm{C}$ for $10 \mathrm{~min},(2) 95^{\circ} \mathrm{C}$ for $30 \mathrm{~s}$, (3) $65^{\circ} \mathrm{C}$ for $60 \mathrm{~s}$, (4) $72^{\circ} \mathrm{C}$ for $30 \mathrm{~s},(5)$ repeat Steps $2-4$ for 14 cycles $\left(-1^{\circ} \mathrm{C}\right.$ each cycle for 15 cycles), (6) $95^{\circ} \mathrm{C}$ for $30 \mathrm{~s}$, (7) $50^{\circ} \mathrm{C}$ for $60 \mathrm{~s}$, (8) $72^{\circ} \mathrm{C}$ for $30 \mathrm{~s}$, (9) repeat Steps $6-8$ for 29 cycles, followed by a final elongation step of $72^{\circ} \mathrm{C}$ for $10 \mathrm{~min}$.

Primers for the papillomavirus PCR assay were developed from an alignment of representative viruses from known papilloma genera. Cycling parameters were: $95^{\circ} \mathrm{C}$ for $5 \mathrm{~min}$, followed by 45 cycles of $95^{\circ} \mathrm{C}$ for $30 \mathrm{~s}, 45^{\circ} \mathrm{C}$ for $45 \mathrm{~s}, 72^{\circ} \mathrm{C}$ for $60 \mathrm{~s}$, and a final elongation step of $72^{\circ} \mathrm{C}$ for $10 \mathrm{~min}$.

Brucella spp. PCR for known terrestrial and marine Brucella species (University of Illinois, Zoological Pathology Program Molecular Diagnostics Laboratory, Chicago, IL, USA) was performed as previously described (Venn-Watson et al. 2015), with modifications for use with FFPE tissues (Delaney et al. 2013). Apicomplexa PCR known to broadly amplify apicomplexan protozoa, including T. gondii, was also performed as previously described (Sledge et al. 2011) using an annealing temperature of $60^{\circ} \mathrm{C}$.

Positive controls included (1) synthetic plasmids containing primer binding sites, (2) a clinical positive case (provided by Drs. Amy Fox and Tylis Chang, the Albert Einstein College of Medicine of Yeshiva University, Bronx, NY, USA), or a vaccine for IA (Fluzone ${ }^{\circledR}$ Influenza Vaccine, Lot\#UH905AA, Sanofi Pasteur), (3) poxvirus-, papillomavirus-, or apicomplexa-positive FFPE or fresh frozen tissue from a pudu (deerpox) or sheep (ORF/parapox), snow leopard (papillomavirus), and rock hyrax (apicomplexa/T. gondii), respectively, and (4) a B. ceti-positive bottlenose dolphin (Tursiops truncatus) fresh, frozen tissue sample. A no-DNA template negative control was included in all assays.

Subsets of samples for the above IHC and PCR testing were selected from samples across years and, when possible, from both samples with or without histologic lesions. Sample inclusion also took into consideration those locations likely to contain histologic lesions of select pathogens significant in marine mammal health, for example, brain and lung were chosen for CDV, T. gondii, and Brucella spp. IHC and CeMV, apicomplexa, IA, and Brucella spp. PCR, and skin was chosen for CeMV, poxvirus, and papillomavirus PCR.

\section{Statistical analyses}

Statistical analyses along with standard ANOVAs or nonparametric tests were performed in $\mathrm{R}$ ( $\mathrm{R}$ Version 3.1.0 [2014-04-10]). ANOVAs were reported for calf length analyses as a proxy for age (Marón et al. 2015), which largely met standard ANOVA assumptions. Kruskal-Wallis tests were reported for analyses of ranked carcass condition code, with bone marrow and cellularity.

\section{RESULTS}

\section{Age class and age estimates}

From 2003 to 2012, 605 SRWs stranded along the coast of PV (Fig. 1). Based on body length (snout to fluke notch) and other physical morphologic features (Table 1), 544 were calves-of-the-year (89.9\%), 


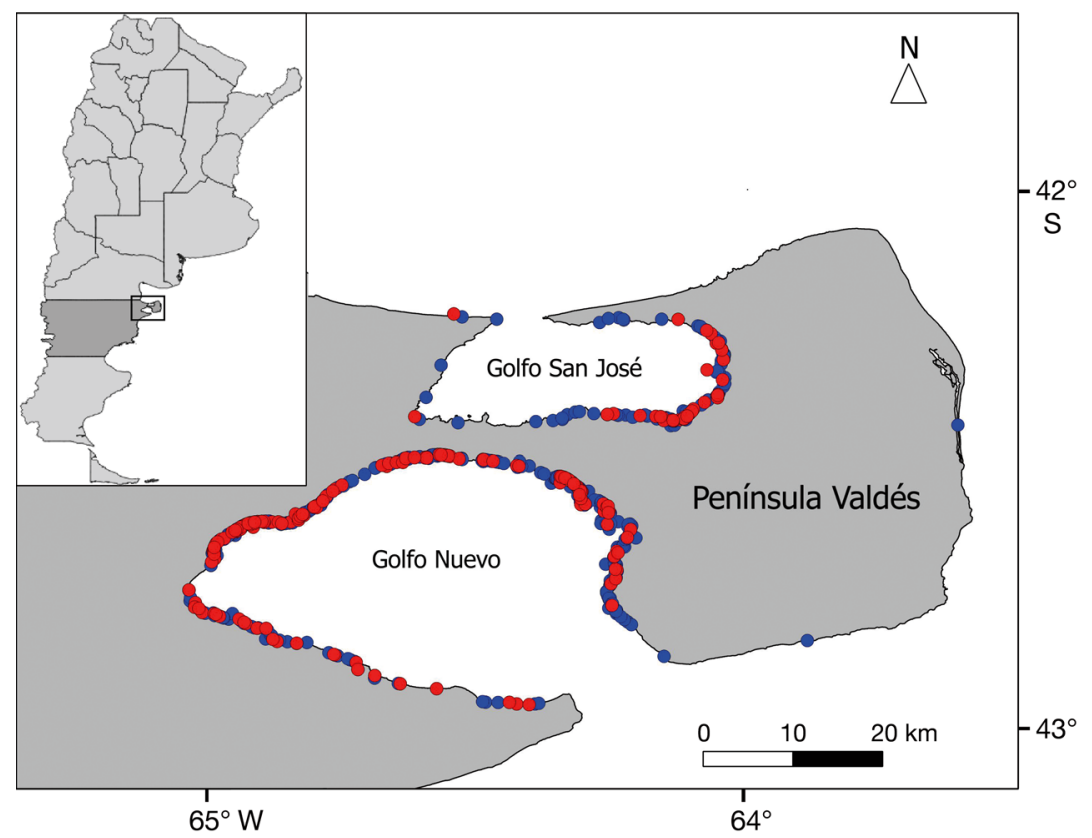

Fig. 1. Map showing 605 southern right whale (SRW; Eubalaena australis) stranding locations along the coast of Península Valdés, Argentina, 2003-2012. Each point corresponds to an individual whale stranding. Red points represent the 212 stranded SRWs from which tissues for this report were collected
$(1.4 \%)$ were morphologically categorized as newborns; $23(10.9 \%)$, as newborn to neonate (ventral recumbency prevented visualization of umbilicus and more specific categorization); $74(34.9 \%)$, as neonates; $88(41.6 \%)$, as $1-2$ mo old calves; and $20(9.4 \%)$ were estimated to be 4-6 mo old (Table 2). The remaining 4 SRWs were 2 juveniles $(0.9 \%)$ and 2 adults $(0.9 \%)$. Further, 103 of the whales were male $(48.6 \%), 95$ were female $(44.8 \%)$, and $14(6.6 \%)$ were of undetermined gender due to carcass position or advanced decomposition (Table 2). None of the whales were thought to be stillborn, as lung from all examined SRWs floated in seawater. Gastrointestinal content (location and type) was inconsistently recorded and therefore was not used in age estimations.
18 were juveniles $(3.0 \%), 34$ were adults $(5.6 \%)$, and age was not recorded or could not be determined in the remaining 9 whales $(1.5 \%)$. Samples from 212 were available for histologic examination and ancillary diagnostic testing. Of the 212, 208 SRWs were calves-of-the-year (98.1\%). Of these, 3

\section{General gross and histologic findings}

Carcasses from which samples were collected were in condition codes 2 through 4 (Table 2). The majority were in condition code 4 ( $\mathrm{n}=125$;

Table 2. Eubalaena australis. Southern right whales by year, gender, carcass condition code, and estimated age. All tissues for histologic examination were from first-season calves with the exception of a 2006 Code 4 adult female (092806PVEa12), a 2008 Code 2 juvenile of undetermined gender (071208PVEa04), a 2010 Code 2 adult female (070910PVEa01), and a 2011 Code 4 juvenile of undetermined gender (091011PVEa28). Undet.: undetermined gender due to carcass position or advanced decomposition; J: juvenile; A: adult; carcass condition codes - 1: alive when first reported/investigated; 2: freshly dead; 3: moderately decomposed but tissues largely intact; 4: advanced decomposition; 5: mummified or skeletonized. Newb-neo.: newbornneonate

\begin{tabular}{|c|c|c|c|c|c|c|c|c|c|c|c|c|c|c|}
\hline \multirow[t]{3}{*}{ Year } & \multirow{3}{*}{$\overline{\text { Male }}$} & \multicolumn{2}{|c|}{ - Gender } & \multirow{2}{*}{\multicolumn{4}{|c|}{$\begin{array}{l}\text { Carcass condition } \\
\text { code }\end{array}$}} & \multirow{3}{*}{$\begin{array}{l}\text { Newborn } \\
\text { (1 d) }\end{array}$} & \multirow{3}{*}{$\begin{array}{l}\text { Newb-neo. } \\
\text { (1 d-2 wk) }\end{array}$} & \multicolumn{2}{|c|}{ Estimated age } & \multirow{3}{*}{$\begin{array}{l}\text { Old calf } \\
(4-6 \mathrm{mo})\end{array}$} & \multirow{3}{*}{$\mathrm{J}$} & \multirow{3}{*}{ A } \\
\hline & & Female & Undet. & & & & & & & Neonate & Young calf & & & \\
\hline & & & & 1 & 2 & 3 & 4 & & & $(<2 \mathrm{wk})$ & (1-2 mo) & & & \\
\hline 2003 & 2 & 5 & 0 & 0 & 1 & 4 & 2 & 0 & 2 & 4 & 1 & 0 & 0 & 0 \\
\hline 2004 & 1 & 3 & 0 & 0 & 1 & 3 & 0 & 1 & 1 & 2 & 0 & 0 & 0 & 0 \\
\hline 2005 & 5 & 5 & 1 & 0 & 3 & 3 & 5 & 0 & 0 & 5 & 6 & 0 & 0 & 0 \\
\hline 2006 & 1 & 4 & 0 & 0 & 1 & 2 & 2 & 0 & 0 & 3 & 0 & 1 & 0 & 1 \\
\hline 2007 & 1 & 3 & 1 & 0 & 1 & 2 & 2 & 0 & 0 & 0 & 1 & 4 & 0 & 0 \\
\hline 2008 & 17 & 17 & 4 & 0 & 2 & 8 & 28 & 0 & 5 & 5 & 23 & 4 & 1 & 0 \\
\hline 2009 & 17 & 10 & 0 & 0 & 5 & 7 & 15 & 0 & 1 & 8 & 17 & 1 & 0 & 0 \\
\hline 2010 & 7 & 7 & 1 & 0 & 4 & 8 & 3 & 0 & 2 & 6 & 4 & 2 & 0 & 1 \\
\hline 2011 & 17 & 18 & 4 & 0 & 1 & 14 & 24 & 1 & 8 & 13 & 10 & 6 & 1 & 0 \\
\hline 2012 & 35 & 23 & 3 & 0 & 2 & 15 & 44 & 1 & 4 & 28 & 26 & 2 & 0 & 0 \\
\hline Total & 103 & 95 & 14 & 0 & 21 & 66 & 125 & 3 & 23 & 74 & 88 & 20 & 2 & 2 \\
\hline
\end{tabular}


$59.0 \%$ ), fewer were in condition code 3 ( $\mathrm{n}=66$; $31.1 \%)$ or $2(\mathrm{n}=21 ; 9.9 \%)$. Histologic examination was performed on a total of 971 samples from 43 different tissue types (Table 3). Two or more tissue types were received from $129(60.8 \%)$ of the 212 whales. Gross and histologic assessment and interpretation, as well as conclusions related to a cause or possible cause of death were highly dependent on tissue preservation and availability. Post-mortem autolysis was evident in all cases and was consistent with carcass condition code. Notable histologic findings were most often seen in non-umbilical skin from sites of ante-mortem gull parasitism (often multiple lesions per sample), adipose tissue, or the respiratory system (Table 3). A cause or lesion/s likely to have contributed to death was/were identified in 13 calves and 1 juvenile whale $(6.6 \%$ overall) (Table 4$)$ but not in the remaining calves $(n=195)$, juveniles $(n=1)$, or adults $(\mathrm{n}=2)$.

\section{Trauma}

Gross findings consistent with trauma as the cause or a likely factor in death were documented in 6 of $212(2.8 \%)$ SRWs (Table 4). A known ship strike occurred in 1 juvenile (071208PVEa04; Golfo Nuevo, Puerto Madryn Beach). Lacerations were seen in 2 neonates (080812PVEa16 and 082512PVEa28), and evidence of blunt force trauma was seen in a neonate (081603PVEa07) and 2 calves that were 1-2 mo old (072512PVEa08 and 092312PVEa67). Entanglement in fishing or mooring gear or other types of marine debris, or trauma consistent with past entanglement, was not identified in these or the remaining SRWs.

Table 3. Eubalaena australis. Histologic tissue examination and summary of histologic lesions. Each finding represents tissue from an individual whale even if multiple tissue samples of the same tissue type were examined. Aspiration includes intrabronchiolar and/or intra-alveolar foreign material, bacteria, protozoa, and/or squames. Gastrointesintal tract inflammation includes inflammation in the esophagus, small or large intestine, or liver. Gastrointestional degeneration is hepatic lipidosis. Respiratory inflammation includes bronchopneumonia, interstitial pneumonia, and intra-alveolar histiocytosis. All non-umbilical trauma in the skin was at sites of gull wounds and includes epidermal clefts, erosions, ulceration, or necrosis. All nonumbilical inflammation in the skin was at sites of gull wounds and includes superficial or deep dermatitis, epidermal hyperplasia, dermal neovascularization, epidermal or dermal vasculitis, dermal fibrosis, or myositis. SRW: southern right whale; NOS: not otherwise specified

\begin{tabular}{|c|c|c|c|c|c|c|c|c|c|c|c|c|}
\hline $\begin{array}{l}\text { Tissue or } \\
\text { organ system }\end{array}$ & 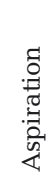 & 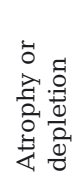 & 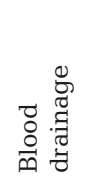 & 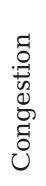 & 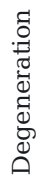 & 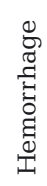 & 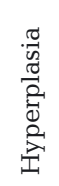 & 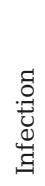 & 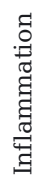 & $\begin{array}{l}0 \\
0 \\
0 \\
0 \\
0 \\
0 \\
Z\end{array}$ & 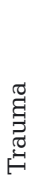 & 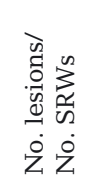 \\
\hline Totals & 22 & 18 & 3 & 2 & 2 & 7 & 50 & 2 & 73 & 10 & 81 & \\
\hline Adipose tissue (cavitary) & & 14 & & & & & & & & & & $14 / 20$ \\
\hline Connective tissue & & & & & & 1 & & & 6 & & & $7 / 27$ \\
\hline $\begin{array}{l}\text { Integumentary system } \\
\text { Umbilicus }\end{array}$ & & & & & & & & & 5 & & & $5 / 5$ \\
\hline Non-umbilicus & & & & & & & 50 & 1 & 40 & 9 & 81 & $181 / 95$ \\
\hline Special senses ${ }^{\mathrm{a}}$ & & & & & & & & & & & & $0 / 2$ \\
\hline Cardiovascular system $^{b}$ & & & & & & & & & 3 & & & $3 / 92$ \\
\hline Endocrine system ${ }^{c}$ & & & & & & & & & & & & $0 / 8$ \\
\hline Gastrointestinal system ${ }^{\mathrm{d}}$ & & & & & 2 & & & & 4 & & & $6 / 160$ \\
\hline Hematopoietic system $^{e}$ & & 4 & 3 & & & 1 & & & & & & $8 / 183$ \\
\hline Musculoskeletal system ${ }^{\mathrm{f}}$ & & & & & & 1 & & & & & & $1 / 72$ \\
\hline Nervous system $^{g}$ & & & & 2 & & 2 & & & 2 & & & $6 / 30$ \\
\hline Reproductive system $^{\mathrm{h}}$ & & & & & & & & & & & & $0 / 82$ \\
\hline Respiratory system ${ }^{i}$ & 22 & & & & & 2 & & 1 & 12 & & & $37 / 87$ \\
\hline Urinary system ${ }^{\mathrm{j}}$ & & & & & & & & & 1 & 1 & & $2 / 108$ \\
\hline
\end{tabular}


Table 4. Eubalaena australis. Cause or suspected cause of southern right whale death. Only whales in which a cause of death was determined or suspected are included. Carcass condition codes: see Table 2. F: female; M: male; U: undetermined; Y: yes; $\mathrm{N}$ : no; NA: unable to determine due to carcass position or post-mortem skin loss

\begin{tabular}{|c|c|c|c|c|c|c|c|}
\hline Animal ID & Year & $\begin{array}{l}\text { Estimated age or } \\
\text { age class }\end{array}$ & Gender & $\begin{array}{l}\text { Body length } \\
\text { (m) }\end{array}$ & $\begin{array}{c}\text { Carcass } \\
\text { condition code }\end{array}$ & Gull & Cause or suspected cause \\
\hline 092503PVEa20 & 2003 & Newborn-neonate & $\mathrm{F}$ & 4.55 & 3 & $\mathrm{~N}$ & Interstitial pneumonia $^{\mathrm{a}}$ \\
\hline 112205PVEa42 & 2005 & $1-2$ mo calf & M & 6.61 & 2 & $\mathrm{Y}$ & $\begin{array}{l}\text { Infected gull wound, interstitial } \\
\text { pneumonia }{ }^{\mathrm{a}} \text {, hepatitis }\end{array}$ \\
\hline 092909PVEa59 & 2009 & Neonate & $\mathrm{F}$ & 5.85 & 4 & NA & Bronchopneumonia w/fungus \\
\hline 082211PVEa12 & 2011 & Neonate & $\mathrm{M}$ & 4.84 & 3 & NA & Bronchopneumonia \\
\hline 071609PVEa06 & 2009 & $1-2$ mo calf & M & 5.05 & 2 & $\mathrm{~N}$ & Meningitis $^{\mathrm{a}}$ \\
\hline 071412PVEa04 & 2012 & Newborn-neonate & M & 5.00 & 3 & $\mathrm{~N}$ & Myocarditis, meningitis \\
\hline 081912PVEa24 & 2012 & 1-2 mo calf & $\mathrm{F}$ & 6.87 & 2 & $\mathrm{Y}$ & Myocarditis \\
\hline $082512 \mathrm{PVEa} 27$ & 2012 & Newborn-neonate & M & 4.70 & 3 & $\mathrm{Y}$ & Myocarditis \\
\hline 081603PVEa07 & 2003 & Neonate & $\mathrm{F}$ & 4.68 & 3 & $\mathrm{~N}$ & Trauma (blunt force type) \\
\hline 071208PVEa04 & 2008 & Juvenile & $\mathrm{U}$ & Juvenile & 2 & NA & Trauma (ship strike) \\
\hline 072512PVEa08 & 2012 & $1-2$ mo calf & $\mathrm{F}$ & 5.37 & 4 & NA & Trauma (blunt force type) \\
\hline 080812PVEa16 & 2012 & Neonate & $\mathrm{F}$ & 4.99 & 4 & NA & Trauma (lacerations) \\
\hline 082512PVEa28 & 2012 & Neonate & M & 3.61 & 4 & $\mathrm{Y}$ & Trauma (lacerations) \\
\hline 092312PVEa67 & 2012 & $1-2$ mo calf & $\mathrm{F}$ & 6.02 & 4 & $\mathrm{~N}$ & Trauma (blunt force type) \\
\hline
\end{tabular}

\section{Aspiration and pneumonia}

Lung samples from a total of 80 whales (3 newborns, 16 newborn to neonates, 38 neonates, 22 of the 1-2 mo old calves, and a 4-6 mo old calf) were received for histologic examination. Intra-alveolar squames, bacteria, protozoa, and/or foreign material consistent with aspiration were present in the lungs of $22(27.5 \%)$ whales. Few, moderate, or numerous aspirated squames (squames/40 $\times$ field $\times 10$ random fields) were seen in 17 SRWs: a newborn $(\mathrm{n}=0,0,1$, respectively), 3 newborn to neonates $(\mathrm{n}=0,2,1$, respectively), 8 neonates ( $\mathrm{n}=6,2,0$, respectively), and 5 young $1-2$ mo old calves $(n=3,2,0$, respectively). There was no statistical association between mean whale length (as a proxy for age) and the presence of aspirated squames ( 2 -sided $t$-test, $\mathrm{p}=0.356$ ). Aspirated meconium was not seen in any of the lung samples.

Aspirated squames were not, in general, associated with tissue response $(\mathrm{n}=11)$ (Fig. $2 \mathrm{a} ; 081411 \mathrm{PV}$ Ea07). However, they were associated with few to moderate numbers of histiocytes in 6 calves: a newborn to neonate with interstitial pneumonia (092503 PVEa20), 2 neonates (081303PVEa07 and 080910 PVEa06) (Fig. 2b), and 3 calves 1-2 mo of age (09090 3PVEa16, 112205PVEa42, and 071609PVEa06) of which 1 (112205PVEa42) had interstitial pneumonia (Fig. 2c). In addition to aspirated squames, interstitial pneumonia in the 2 calves was similar and characterized by mildly to moderately thickened alveolar septae, mild to moderate multifocal interstitial in- filtrates of uni-, bi-, or multinucleated macrophages, lymphocytes and plasma cells, and occasional intra-alveolar fibrin that lined or occasionally filled alveolar spaces (Fig. 2c). Two additional SRW calves, both neonates (092909PVEa59 and 082211PVEa12), had bronchopneumonia (Fig. 2d). Bronchopneumonia in each case was characterized by airwayoriented inflammation consisting of multifocal to coalescing and regionally extensive areas of necrosis with intra-lesional and intra-alveolar degenerate neutrophils and aggregates of bacteria. In 1 neonate (092909PVEa59), these areas were surrounded by a wide band of lymphoplasmacytic and histiocytic inflammation and fibroplasia. An additional interesting finding in this calf was the presence of a few, intra-lesional, non-septate, non-parallel walled, fungal hyphae (Fig. 2d, inset); fungal PCR performed to better characterize these organisms did not produce any amplified products (University of Illinois, Zoological Pathology Program Molecular Diagnostics Laboratory, Chicago, IL, USA; methods per Delaney et al. 2013). Aspirated squames were not seen in either case. Pneumonia was considered significant and a likely contributing factor or cause of death in the 4 calves in which it was seen (Table 4). Inclusions consistent with known viruses were not seen histologically in respiratory tract samples from any SRW.

IHC for CDV, T. gondii and Brucella spp. was performed on lung tissue from 10 calves: 2 with interstitial pneumonia and aspirated squames, 2 with bronchopneumonia, 5 with aspiration (4 with 

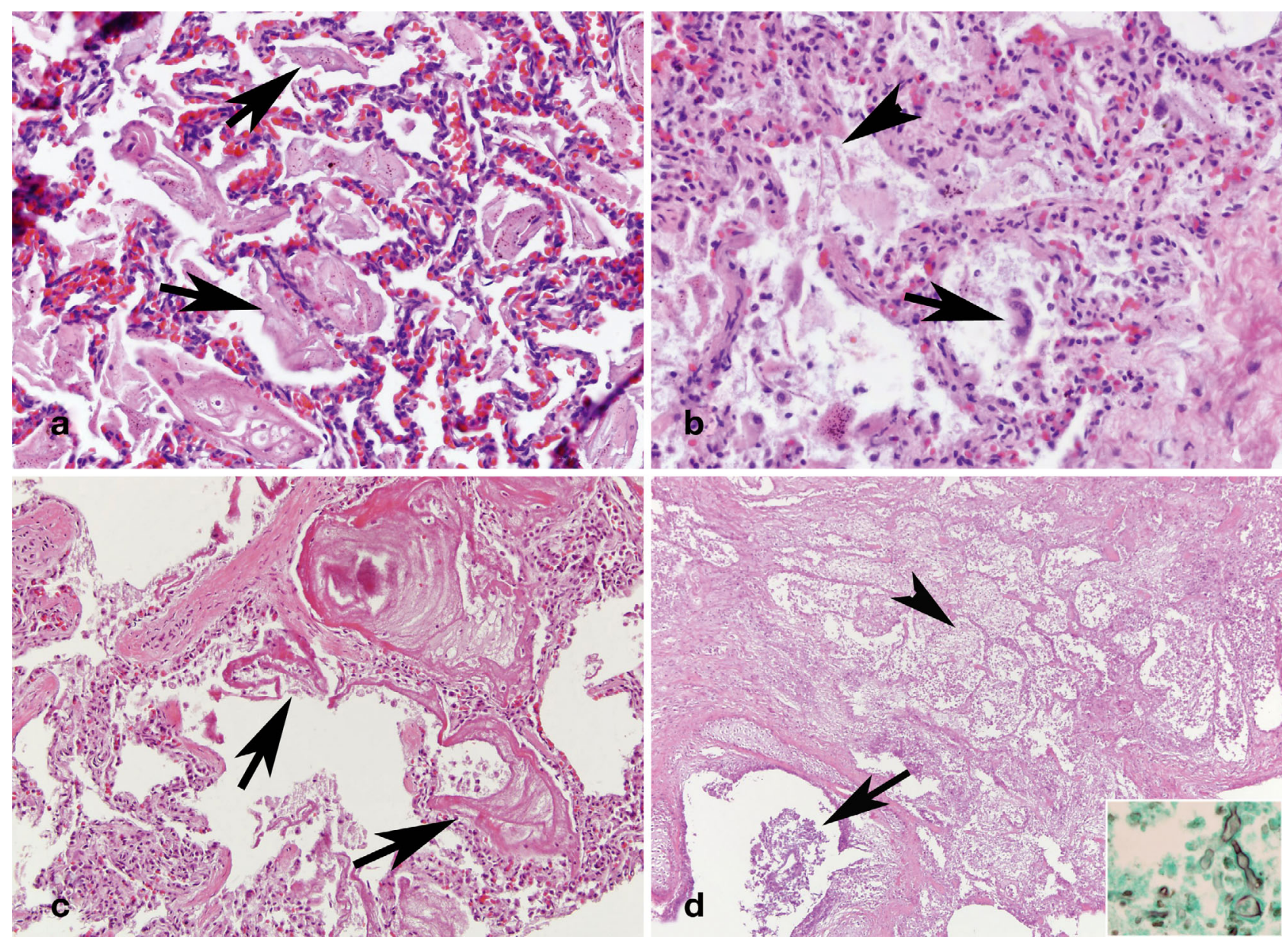

Fig. 2. Eubalaena australis. Lung. (a) Male SRW calf (081411PvEa07; $3.64 \mathrm{~m}$; newborn). Normal pulmonary interstitium and numerous intra-alveolar squames (arrows) with no associated parenchymal or lumenal inflammation or other tissue reaction. In this whale, squames were found in multifocal intra-alveolar aggregates in approximately $5 \%$ of the examined lung tissues. Hematoxylin and eosin (HE); 400x. (b) Female SRW calf (080910PVEa06; $4.1 \mathrm{~m}$; neonate). Mild alveolar histiocytosis with multi-nucleated histiocytes (arrow) and moderate numbers of intra-alveolar squames (arrowhead). HE; 400×. (c) Male SRW calf (112205PVEa42; $6.61 \mathrm{~m} ; 1-2 \mathrm{mo}$ old). Interstitial pneumonia characterized by multifocal, abundant intra-lumenal fibrin accumulation (arrows) and mild interstitial infiltrates of lymphocytes, plasma cells, and macrophages. HE; 200×. (d) Female SRW calf (092909PVEa59: 5.85 m; neonate). Severe bronchopneumonia with bronchiolar (arrow) and intra-alveolar (arrowhead) inflammation. $\mathrm{HE}_{\mathrm{i}}$ 100x. Inset: Non-parallel walled, aseptate, intra-lesional fungal hyphae; bulbous segments are highlighted gray with Gomori methenamine silver (GMS) staining; 1000×

aspirated squames, 3 also having histiocytosis), and 1 with no histologic lesions (Table S2 in the supplement at www.int-res.com/articles/suppl/d119p017 supp.pdf). IHC for each pathogen was negative in 7 and inconclusive in 3 (2 SRWs with bronchopneumonia, 1 with aspirated squames and histiocytosis) due to failure of labeling with the internal AE1/AE3 positive control. PCR for CeMV and IA was negative in 9 and inconclusive in 1 (with aspiration and histiocytosis) due to failure of amplification of the internal GAPDH control. Apicomplexa PCR was negative in all lung samples. Brucella spp. PCR was negative in 9 and positive in the newborn to neonatal calf (092503PVEa20) with interstitial pneumonia and aspirated squames.

\section{Extra-pulmonary parenchymal and multi-organ inflammation}

Extra-pulmonary parenchymal inflammation suspected of causing or contributing to death was identified in 5 calves (Table 4). These cases included myocarditis in a newborn to neonate $(082512$ PVEa27) and a 1-2 mo old calf (081912PVEa24), meningitis in a 1-2 mo old calf (071609PVEa06), 
myocarditis and meningitis in a newborn to neonate (071412PVEa04), and hepatitis in a 1-2 mo old calf (112205PVEa42) that also had aspirated squames, interstitial pneumonia (see above for additional description), and gull predation wounds. In this last calf, hepatitis (Fig. 3) was characterized by severe, multifocal to coalescing areas of hepatic necrosis, with infiltrates of lymphocytes, plasma cells, and fewer degenerate neutrophils. In cases with meningitis (Fig. 4), inflammation mildly to moderately expanded the meninges, was multifocal, mild to severe, and was primarily histiocytic, with fewer lymphocytes and plasma cells. Inflammation was not seen in underlying brain. Myocarditis (Fig. 5) was multifocal to regionally extensive, consisted primarily of degenerate neutrophils associated with myocardiocyte necrosis, and contained clusters of intralesional coccobacilli or short bacilli (morphologic detail of the bacteria was obscured by autolysis). Myocarditis in the calf with meningitis was more severe than in the 2 calves without meningitis. Neither of the latter 2 calves had inflammatory or other lesions in parenchymal organs, including the brain, liver, kidney, or lung; both had gross evidence of gull predation wounds, but skin from these whales was not available for histologic examination. Inclusions consistent with known viruses were not seen histologically in any non-respiratory tract tissues, including nervous tissue from 30 whales.

IHC for CDV and T. gondii and PCR for CeMV and apicomplexan protozoa were performed on brain tis-

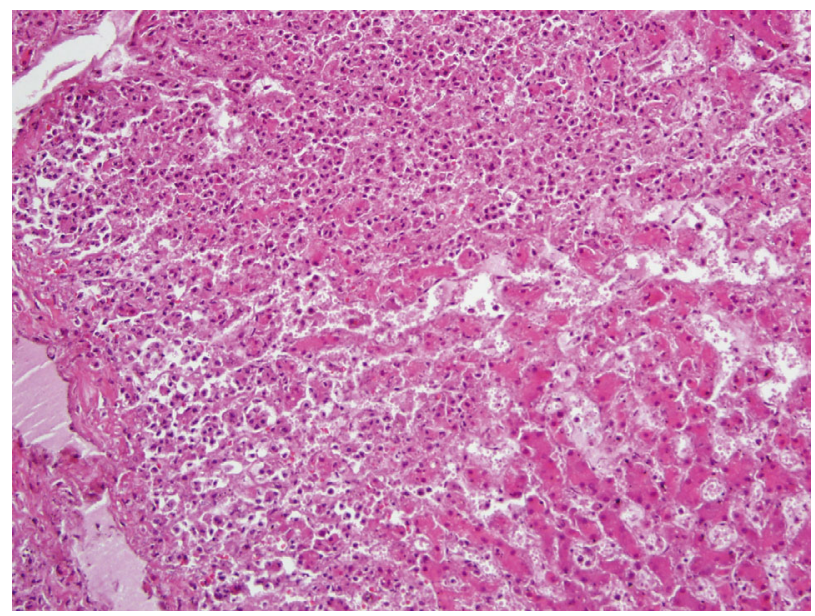

Fig. 3. Liver. Male SRW calf (112205PVEa42; $6.61 \mathrm{~m}$; 1-2 mo old). Hepatitis. Inflammation, composed primarily of lymphocytes, plasma cells, and fewer degenerate neutrophils, is associated with multifocal to coalescing areas of hepatic necrosis. This SRW also had gross and histologic lesions consistent with ante-mortem gull-inflicted trauma and interstitial pneumonia (Fig. 2c). HE; 200x sue from 11 calves (Table S2). Ten had no histologic lesions, and one was a 1-2 mo old calf with meningitis (071609PVEa06); IHC for Brucella spp. was also performed on this calf (tissue was not available from the newborn to neonate [071412PVEa04] with meningitis and myocarditis). IHC for $\mathrm{CDV}$ and $T$.

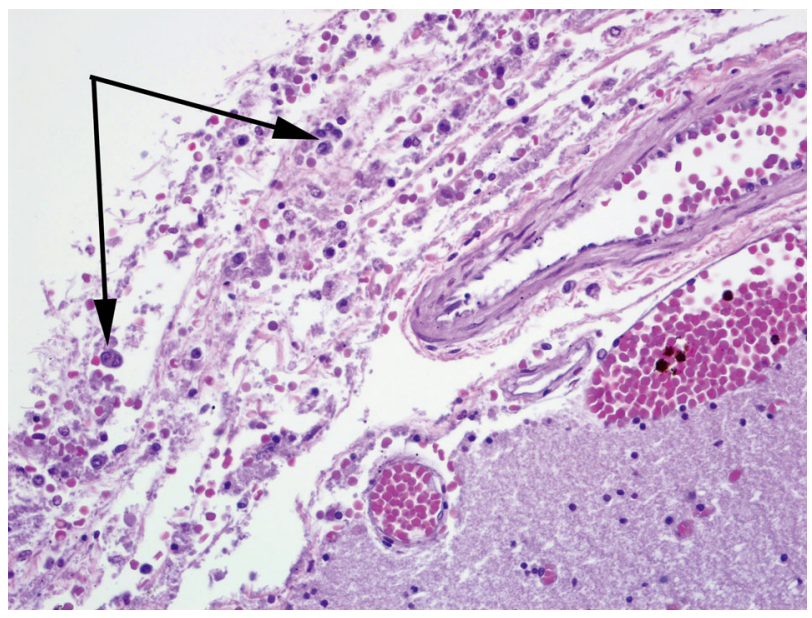

Fig. 4. Eubalaena australis. Meninges. Male SRW calf (071 609PVEa 06; $5.05 \mathrm{~m} ; 1-2$ mo old). Meningitis. The meninges are moderately expanded and contain an inflammatory infiltrate consisting primarily of macrophages with fewer lymphocytes and plasma cells (arrows). Histologically normal subjacent brain is present in the lower right hand corner of the image. $\mathrm{HE}_{;} 200 \times$

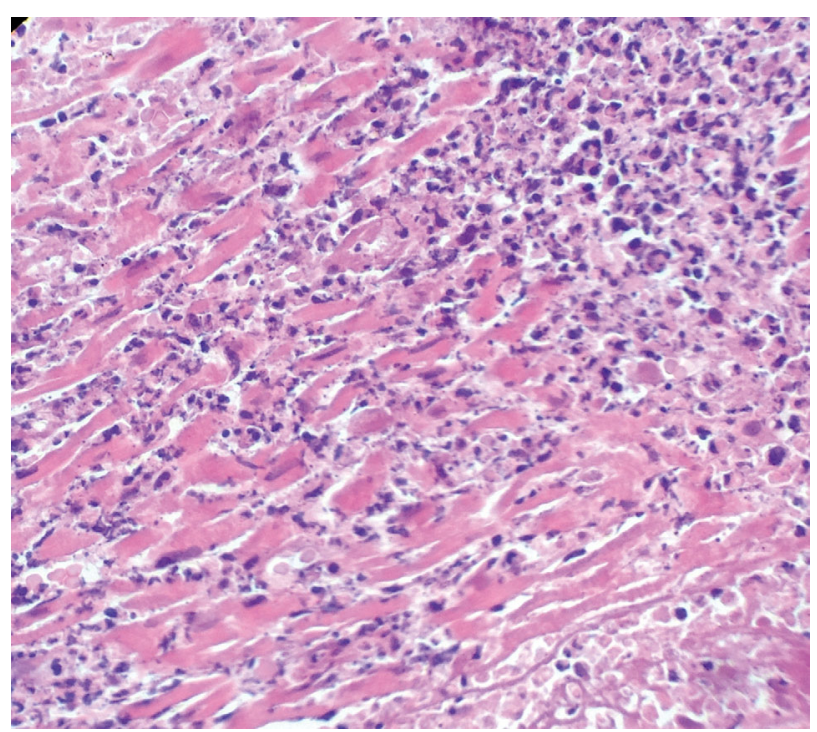

Fig. 5. Eubalaena australis. Heart. Male SRW calf $(071412$ PVEa04; $5.00 \mathrm{~m}$; newborn to neonate). Myocarditis. Myocarditis with degenerate inflammatory cells that replace and infiltrate between myofibers. Multifocal to regionally extensive inflammation consisting primarily of degenerate neutrophils, replaces and infiltrates between myofibers and is associated with myocardiocyte necrosis. $\mathrm{HE}_{\mathrm{i}} 400 \times$ 
gondii was negative in all 11 cases, as was Brucella spp. IHC in the neonate with meningitis. PCR for CeMV was negative in this neonate and 8 additional calves with histologically normal brain; it was inconclusive in the 2 remaining calves due to failure of amplification of the internal GAPDH control. Apicomplexan protozoa PCR was negative in 8 cases and was inconclusive in 3 calves (including 071609PVE a06) due to failure of amplification of the internal GADPH control.

\section{Gull-inflicted skin wounds}

Gross skin lesions (Fig. 6a,b) consistent with antemortem gull predation were present in 80 of the 212 SRWs, undetermined due to carcass position or postmortem skin loss in 40 and 36 whales, respectively, not assessed in 4, and not present in the remaining 52 whales. This included wounds in 2 neonate to newborns, 6 neonates, 58 and 13 calves estimated to be 1-2 mo or 4-6 mo old, respectively, and in 1 adult. Skin from predation sites was available for histologic examination from 56 of the affected SRWs; it was the only tissue examined histologically in 38. Lesions consistent with ante-mortem trauma were histologically confirmed in 38 of the 56 whales of which the majority were $1-2$ mo old calves $(\mathrm{n}=28)$. The remainder were 6 calves aged 4-6 mo, 2 neonates, a newborn-neonate and an adult. Complications associated with ante-mortem gull predation wounds as a possible factor in the death were seen in a single, 1-2 mo old calf that stranded in November 2005 in Golfo Nuevo (112205PVEa42; see above 2 subsections for additional descriptions; Table 4). Skin from an additional 15 whales without gross evidence of gull predation was also reviewed; histologic lesions were not identified in any of the skin samples that did not have gross evidence of trauma.

In skin with gross lesions, samples for histologic examination typically included epidermis, dermis (papillae and reticular), and hypodermis. Most histologic lesions were present in the epidermis and dermal papillae. These included epidermal clefts $(\mathrm{n}=$ $34)$, erosions $(n=34)$, hyperplasia $(n=22)$, and/or inflammation in the epidermis or dermal papillae $(\mathrm{n}=$ 18), or reticular dermis $(n=17)$ (Fig. 6d-f). Inflammation in hypodermis or subjacent muscle was relatively uncommon $(\mathrm{n}=3)$. Inflammatory cell infiltrates were consistent with chronicity and other findings. For example, acute lesions, especially those with ulceration, were typically associated with mixed neutrophilic and lymphoplasmacytic inflammation of the dermal papillae, epidermis, and/or the superficial dermis, while more chronic lesions were more often associated with no inflammation or very mild lymphoplasmacytic infiltrates in the dermal papillae and superficial dermis, mild fibroplasia in the superficial dermis, and/or epidermal hyperplasia with wide rete peg formation. Erosion with dermatitis $(n=17)$ occurred as often as erosion without dermatitis ( $\mathrm{n}=$ 17). Ulceration was seen both without $(n=5)$ and with ( $\mathrm{n}=8$; Fig. 6f) dermatitis. Skin wounds and epidermal ulceration and dermatitis with intra-lesional bacteria was seen in a 1-2 mo old calf (112205 PVEa42) that also had hepatitis (Fig. 3) and interstitial pneumonia (Fig. 2c) (see above 2 subsections for additional descriptions). The combination of multiorgan inflammation and intra-lesional bacteria in the ulcerated skin of this calf suggested a related process, and bacterial sepsis was considered a likely cause or contributing factor in its death. Bacterial infection or inflammation was not seen at other sites, including lung $(\mathrm{n}=7)$, kidney $(\mathrm{n}=6)$, liver $(\mathrm{n}=4)$, heart $(\mathrm{n}=3)$, brain $(\mathrm{n}=3)$, lymph node $(\mathrm{n}=3)$, or spleen $(\mathrm{n}=3)$ in the remaining whales with gull predation wounds $(\mathrm{n}=39)$.

PCR for the $\mathrm{P}$ gene of CeMV, cetacean poxvirus DNA topoisomerase I and DNA polymerase genes, and the L1 gene of papilloma virus was performed on skin samples from 16 calves (Table S3 in the Supplement). Of these samples, 13 were from lesional and 3 were from non-lesional skin. All were negative for poxvirus and papillomavirus targets. Twelve, including 112205PVEa42, were negative for CeMV; CeMV testing in the remaining 4 ( 2 with and 2 without predation lesions) was non-diagnostic as the cetacean GAPDH gene was not amplified in these samples. Other positive and negative PCR controls produced appropriate positive or negative results.

Statistical analysis to assess possible relationships between calf length (as a proxy for age) and gull predation wounds was performed. For the 208 calves, a 1 -way ANOVA revealed calf length as being significantly longer for carcasses with gull wounds (mean $6.25 \mathrm{~m}$; median $6.25 \mathrm{~m}$ ) than for carcasses without gull wounds (mean $5.29 \mathrm{~m}$; median $5.18 \mathrm{~m}),\left(F_{(1,206)}=\right.$ 51.8, $\left.\mathrm{MSE}=0.887, \mathrm{p}=1.10 \times 10^{-11}\right)($ Fig. 7$)$.

\section{Other significant findings}

Atrophy or depletion of adipose tissue in epicardial or perirenal locations was identified histologically in 14 of 20 SRWs (70.0\%) (Table 3). Histological examination and subjective evaluation of cellularity and 

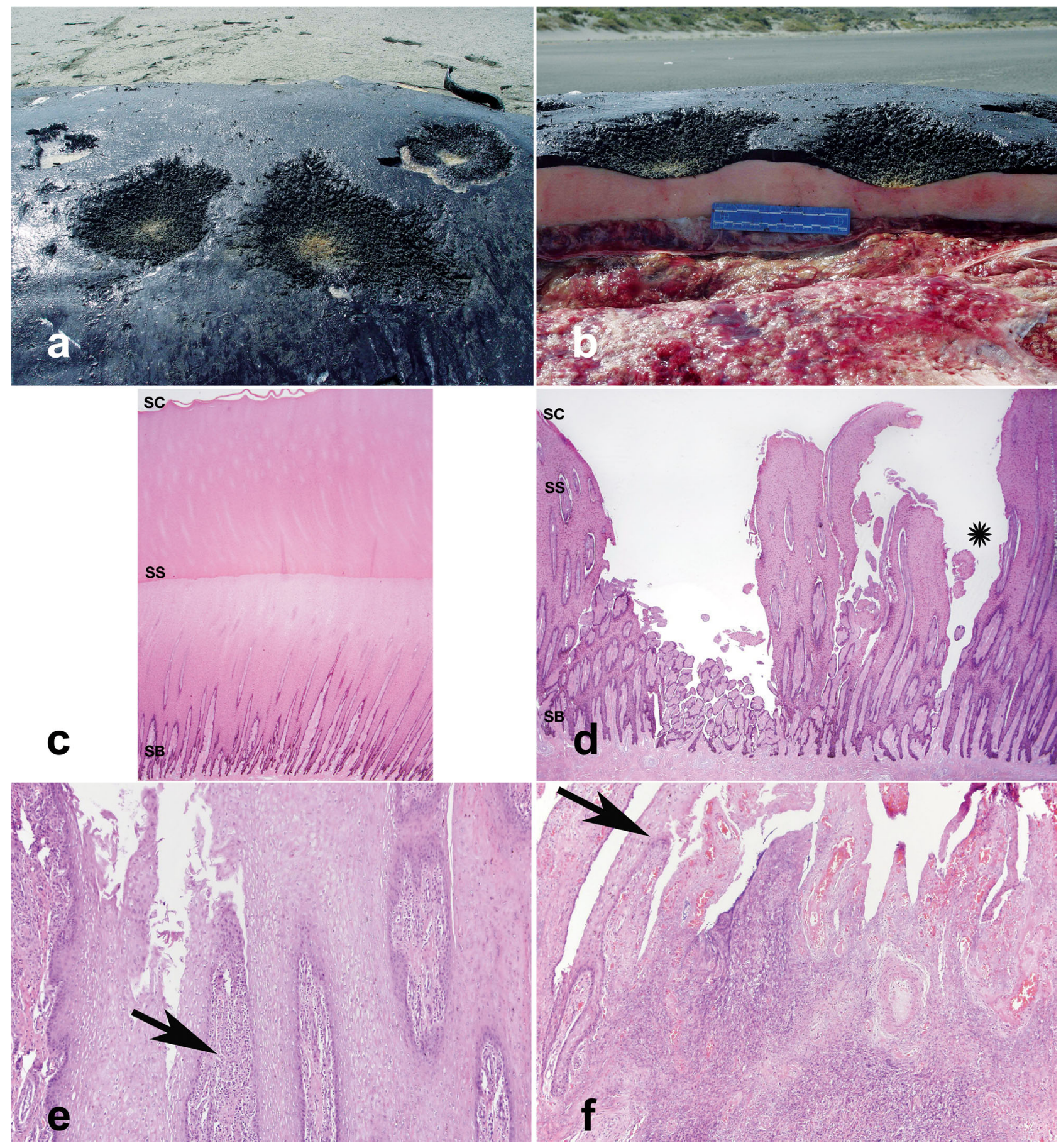

Fig. 6. Eubalaena australis. Skin. Gross (a,b) and histologic (d-f) ante-mortem gull predation wounds. (a) Female SRW calf (110407PVEa56; $8.05 \mathrm{~m}$; 4-6 mo old). Multiple, roughly round, centrally cavitated, partial (peripheral) to full-thickness (central) areas of skin loss. (b). Cross-section through skin of whale in (a) demonstrating the size and depth of the wounds. (c) Histologically normal SRW skin. Highlighted in this sample are the epidermis, consisting of the superficial stratum corneum (SC), stratum spinosum (SS), and stratum basale (SB), and the superficial aspect of the underlying reticular dermis. HE; 20x. (d) Male SRW calf (091708PVEa56; $5.68 \mathrm{~m} ; 1$ 1-2 mo old). Histologic lesions are characterized by epidermal clefts (star) and epidermal erosion, the latter seen as variably deep areas of epidermal loss with retention of the stratum basale. HE; 20x. (e) Male SRW calf (100708PVEa76; $7.45 \mathrm{~m} ; 4-6 \mathrm{mo}$ old). Histologic lesions are characterized by epidermal erosion and lymphoplasmacytic dermatitis in the papillary dermis (arrow). HE; 200x. (f) Female SRW calf (083009PVEa38; 6.25 m; 1-2 mo old). Histologic lesions include ulceration, characterized by epidermal loss and discontinuity of the stratum basale (arrow indicates junction between ulcerated and non-ulcerated epidermis), and significant associated inflammation of the underlying reticular dermis. HE; 100×. Panels a \& b courtesy of M. Sironi, Instituto de Conservación de Ballenas/Ocean Alliance 


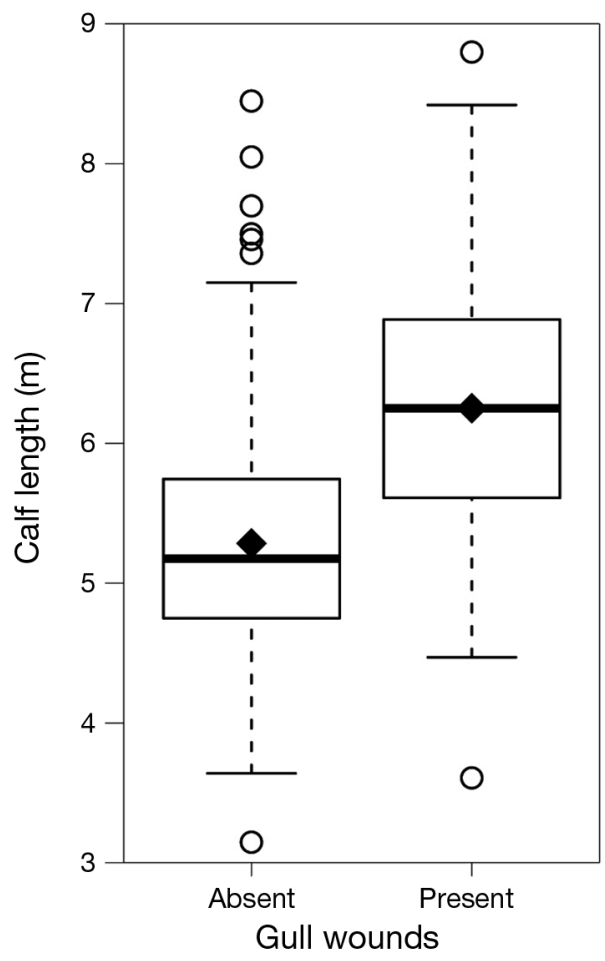

Fig. 7. Eubalaena australis. Box plot of gull wounds and calf length $(\mathrm{m})$. Shown are the median value (bold line), mean (diamond), upper and lower quartiles (box), and 1.5 interquartile range outer limits (whiskers); outliers (open circles) are defined as $>1.5$ times the inter-quartile range

marrow fat content was performed from samples of humerus from 110 of the $212(51.9 \%)$ SRWs. Two samples lacked marrow elements (including bone spicules) and were non-diagnostic, so they were removed from further analysis. The remaining 108 samples (107 calves, 1 juvenile) contained hematopoietic cells, marrow fat, and bone spicules. In 38 $(17.9 \%)$, bone marrow was the only tissue received for histologic examination. Marrow from the juvenile SRW had low cellularity and moderate fat content. In the 107 calves, marrow was more often moderately cellular $(\mathrm{n}=55 ; 51.4 \%)$ than densely cellular $(\mathrm{n}=34$; $31.8 \%)$ or of low cellularity $(\mathrm{n}=18,16.8 \%)$. Marrow commonly lacked fat $(\mathrm{n}=65 ; 60.8 \%)$ and, when present, there was typically low ( $\mathrm{n}=27 ; 25.2 \%$ ) rather than moderate $(n=12 ; 11.2 \%)$ or dense $(n=3 ; 2.8 \%)$ amounts of fat. Kruskal-Wallis tests were used to investigate whether marrow fat and marrow cellularity were influenced by post-mortem degradation (carcass condition code). Ranked carcass condition code was not found to be significantly different for ranked levels of marrow fat $(H=6.21$, df $=3, \mathrm{p}=$ $0.102)$ or cellularity $(H=0.573, \mathrm{df}=2, \mathrm{p}=0.751)$, suggesting that post-mortem degradation had no significant association with marrow fat levels or marrow cellularity.

\section{DISCUSSION}

Annual mortalities of SRWs along the coast of PV, and in particular sustained high numbers of deaths between 2007 and 2012, have prompted international concern and efforts to understand the cause or causes for these losses (IWC 2011, 2014, Rowntree et al. 2013, Thomas et al. 2013). To date, consistent findings within or between years to explain the deaths have not been identified. This is the first long-term study to investigate and summarize notable postmortem findings in the PV population.

\section{Animal demographics}

The most significant, alarming, and consistent findings in SRW mortalities at PV are the high number of deaths in general and high number of dead calves relative to other age classes in particular. Between 2003 and 2012, 544 of 605 (89.9\%) and an average of 60.4 annual deaths were calves-of-the-year. Deaths have occurred across the age range of calves, with 181 being newborn to neonates (33.3\%), 211 being $1-2$ mo of age $(38.8 \%)$, and 152 being $4-6$ mo of age $(27.9 \%)$. To our knowledge, there are no other reports of recurrent high mortality (above $35 \mathrm{yr}^{-1}$; Rowntree et al. 2013) in calves-of-the-year from other SRW populations (Best et al. 2001, Greig et al. 2001) or in other populations of large or small cetaceans worldwide. Additionally, deaths differ in both scale and age class distribution from 2 previous mortality reports in which calves-of-the-year were 9 of 23 $(31 \%)$ of the dead SRWs from 1977 to 1995 (mean = $0.72 \mathrm{yr}^{-1}$ ) off the coast of Brazil (Greig et al. 2001) and 31 of $55(56 \%)$ of the dead SRWs from 1963 to 1998 (average $=0.62 \mathrm{yr}^{-1}$ ) off the coast of South Africa (Best et al. 2001). In these earlier reports, carcasses were typically not examined sufficiently to establish a cause of death, and categorization of ages beyond calf, juvenile/sub-adult, and adult was not performed.

Of the 212 SRWs in this report, 208 of $212(98.1 \%)$ were calves-of-the-year. Of these, almost half (47.2\%) were newborns, neonates, or had morphologic features consistent with these age groups. Numerous factors are associated with in utero or neonatal death, and loss of a certain percentage of perinates (late term fetus, newborn, neonate) or young animals is an 
anticipated outcome of pregnancy in any species. In utero fetal distress can lead to late term abortion, stillbirth, and death in newborns or neonates. Indicators include aspiration of intra-amniotic fetal squames or meconium release into the amniotic fluid prior to parturition (Gould 2007). Significant sequelae are typically associated with plugs of squames or meconium aspiration (Gould 2007). Moderate or numerous aspirated squames were seen in the lungs of a few newborn, neonatal, or older SRW calves. In the newborns and neonates, they could reflect fetal distress, while in the older calves, aspiration probably developed as a terminal event. In either case, because aspiration of squames is a non-specific finding that develops secondary to other pathologic processes, and in the remaining calves-of-the-year, it is important to establish the primary factor/s, as well as sequelae, like fetal distress, for death.

Based on the pattern of mortalities of PV SRWs, participants at several workshops focused on SRW morbidity- and mortality-identified infectious disease, environmental factors (i.e. anthropogenic or biological or chemical toxins), kelp-gull harassment and its effect on whale behavior and health, densitydependent processes and their effects on right whale population dynamics, and food availability and its links to whale body condition and health as the most likely factors contributing to whale deaths (IWC 2001, 2014, Sironi et al. 2014, Thomas et al. 2013). These factors guided our diagnostic approach.

\section{Infectious disease}

Infectious diseases are important causes of single death and mass mortality events in marine mammals (Miller et al. 2004, Guzmán-Verri et al. 2012, VennWatson et al. 2012, VanBressem et al. 2014, Morris et al. 2015). With a high number of calf and perinatal deaths at PV, pathogens that affect reproductive tissues or the feto-maternal interface, that can be vertically or horizontally transmitted from a dam to a fetus or calf, or that are important in newborns and neonates, were of particular concern in our investigation. Bacterial or protozoal infections in marine mammals are typically not associated with large-scale or recurrent die-offs. However, Brucella spp. and toxoplasmosis have been diagnosed in a variety of marine mammal species and are considered emerging diseases in cetaceans (Guzmán-Verri et al. 2012, VanBressem et al. 2014). Transmission of either organism can be vertical or horizontal, and infections can cause placentitis or late term abortion, as well as menin- goencephalitis, meningitis, or pneumonia (Ohishi et al. 2004, VanBressem et al. 2009, Guzmán-Verri et al. 2012, Davison et al. 2013, 2015, West et al. 2013, 2015). Similarities in disease presentation to brucellosis or toxoplasmosis in SRWs include death in a high number of young animals, in particular newborns and neonates, and pneumonia or meningitis in a few. Lung from a newborn to neonatal calf with aspirated squames and interstitial pneumonia (092503PVEa20) was PCR positive but IHC negative for Brucella spp. and negative or inconclusive in 9 others with or without notable pulmonary findings; testing for Toxoplasma gondii and other apicomplexan protozoa was negative or inconclusive in all of these same samples. These findings, together with absence of inflammation and/or infection in most animals and death across a range of calf ages make these or other transplacental or in utero infections an unlikely explanation for most of the calf deaths. However, it does not completely rule out the possibility of in utero infections in at least a subset of the calves, especially in the newborns or neonates, with pneumonia, meningitis, and/or myocarditis. Examination and pathogen testing of placental tissue, which has been recovered from 2 whales, remains to be performed and will provide additional important information.

Viral infections, and in particular cetacean morbilliviruses (CeMV) in the Paramyxoviridae family, have caused some of the most significant recorded small- and large-scale cetacean mortality events (Lipscomb et al. 1994, Van Bressem et al. 2009, 2014, Morris et al. 2015). Individual animal deaths and epizootics in porpoises (porpoise morbillivirus; PMV), dolphins (dolphin morbillivirus; DMV), and odontocete whales (pilot whale morbillivirus; PWMV) have been described since the virus was first reported in marine mammals in the early 1990s (Duignan et al. 1992, Lipscomb et al. 1994, Jauniaux et al. 2000, Fernández et al. 2008, Van Bressem et al. 2009, 2014, Rubio-Guerri et al. 2013, West et al. 2013, Groch et al. 2014, Stephens et al. 2014, Morris et al. 2015). All age classes are typically affected, and, in some cases, morbidity and/or mortality are seen across multiple marine mammal species. The virus is lymphotropic, epitheliotropic, and neurotropic, and common findings in infected animals include pneumonia, prominent lymphoid depletion, non-suppurative meningoencephalitis, syncytial cell formation, and intracytoplasmic and intra-nuclear eosinophilic viral inclusions (Van Bressem et al. 2009, 2014).

Along the South Atlantic coasts of Peru, Brazil, and Argentina, CeMV titers have been detected in small 
cetaceans since 2001 (Van Bressem et al. 2001, 2009, 2014, Groch et al. 2014) and in 2010 it was identified as a cause of death in a marine mammal, a Guiana dolphin Sotalia guianensis, off the coast of Brazil (Groch et al. 2014). At PV, absence of deaths across age classes or in sympatric susceptible species such as sea lions Otaria flavescens, southern elephant seals Mirounga leonina, dusky dolphins Lagenorhynchus obscurus, or common dolphins Delphinus delphis (our team's field observations over the same time period), coupled with our histologic findings and negative PCR and IHC testing, make morbillivirus an unlikely factor in SRW deaths at PV. In addition, our findings also suggest infection with other viruses that produce detectable histologic lesions, including necrotizing inflammation, as is the case with viruses such as Influenza A or herpesvirus, viral syncytial cells, which were a differential for bior multinucleated histiocytes in the lungs of some SRWs, or detectable viral inclusions, as unlikely factors in the death of whales at PV.

\section{Anthropogenic factors}

Ship strike and entanglement in fishing or mooring gear or other types of marine debris are significant causes of morbidity and/or mortality in whales (Best et al. 2001, Knowlton \& Kraus 2001, Moore et al. 2005, Panigada et al. 2006, Campbell-Malone et al. 2008, Cassoff et al. 2011). In some species, like the critically endangered NRW, fatal ship strikes and serious injury or death due to entanglement in fishing gear have been documented in as many as $35.5 \%$ and $55.4 \%$ of dead whales, respectively. In NRWs, these anthropogenic factors are thought to limit population recovery and pose an extinction risk (Knowlton \& Kraus 2001). In our study, a known ship strike occurred in a single juvenile whale, and evidence of blunt force trauma or lacerations, which could have been the result of ship strike or other factors, such as intra- or inter-species interactions or birthing trauma, was seen in an additional 5 calves. Gear entanglement was not seen or suspected in the death of any whale regardless of age class. Our findings reflect a low incidence of ship strike $(0.47 \%$ to $2.8 \%)$ or entanglement relative to that in NRWs and in SRWs in southern Brazil from 1977 to 1995 (13\%) (Greig et al. 2001) and in South Africa from 1963 to 1998 (calves $=6.5-16.1 \%$, juveniles $=25-50 \%$, adults $=$ 35.7-57.1\%) (Best et al. 2001). Trauma from human activities is not currently a significant factor in the high number of SRW deaths in Argentina. However, the number of cases in which trauma was seen in SRWs was higher in $2012(\mathrm{n}=4)$ than in previous years (1 in both 2003 and 2008), and it will be important therefore to continue to monitor this trend, especially in the context of increasing whale-related tourism and other human activities in PV (Rivarola et al. 2001, Sironi et al. 2009).

\section{Chemical pollutants and algal toxins}

Exposure to chemical pollutants or algal biotoxins can negatively affect numerous physiologic functions. Effects on reproduction include in utero death and abortion or developmental abnormalities in fetuses due to transplacental transfer of toxins and/or failure to thrive or death in calves due to ingestion of toxins in milk. Levels of non-essential and essential metals (Gil et al. 2006, Martino et al. 2012, Rosas et al. 2012) from live and dead SRWs and organochlorines and PCBs in dead SRWs (Torres et al. 2015) have recently been investigated. Results showed tissue levels in SRWs that were typically similar to or lower than tissue levels in other mysticetes or cetacean species, including others from the southern hemisphere that were not experiencing unusual mortality.

Península Valdés is a significant source of bivalve mollusks for human consumption in Argentina, and algal toxins and harmful algal blooms (HABs) have been monitored in PV since 1985 (Wilson et al. 2015). In general, elevated HAB species and associated biotoxins such as saxitoxin and domoic acid have not been linked to significant human or animal morbidity or mortality at PV, though biotoxin- or HAB-related human and seabird deaths have periodically occurred (Wilson et al. 2015). In 2 previous studies, low levels of saxitoxin or domoic acid were detected in tissues from dead whales (Wilson et al. 2015), and frustules of potentially toxic Pseudo-nitzschia were identified in feces of living and dead PV SRWs (D'Agostino et al. 2015). However, spatial or temporal relationships between algal biotoxin production and whale mortality peaks were not found. Furthermore, biotoxin levels in SRWs were similar or lower than those in fecal samples from apparently healthy, foraging NRWs, blue whales, and humpback whales in other studies (Lefebvre et al. 2002, Doucette et al. 2006, 2012).

At the light microscopic level, cellular or tissue damage from toxins is often non-specific, though some chemical or biological toxins produce very specific (and occasionally pathognomonic) patterns and types of changes. Evidence of toxic damage was not 
seen in examined tissues from SRWs, including the liver, kidney, heart, and brain - tissues that either detoxify toxins or in which toxic effects can be seen. However, in many cases, tissue preservation was not optimal, and subtle histological changes associated with toxins, for example mild degeneration or necrosis, could have been masked by autolysis. In others, detection of specific lesions, for example degeneration or necrosis in the heart or hippocampus of the brain, reported in birds and sea lions with domoic acid toxicity (Silvagni et al. 2005, Zabka et al. 2009), was limited both by autolysis and, in the case of neural tissue, access to samples (whole brains or brain samples that included hippocampus were rarely collected). Evaluation of relationships between SRW deaths and biological toxins is a topic of ongoing investigation. However, to date, a link between the two has not been established either through analytical methods or histology in years of high SRW mortality at PV. Additionally, a significant relationship is not suspected based on these data, deaths primarily in calves, and absence of observed die-offs in other PV marine mammal species, birds or fish (Shumway et al. 2003, de la Riva et al. 2009).

\section{Other significant findings}

Body condition is an important factor influencing many vital body functions, including reproductive success as well as survival (Miller et al. 2011, 2012). Structural components that contribute to subjective or objective measures of body condition include the integument (epidermis and blubber), skeletal muscle, and cavitary (thoracic and abdominal) adipose tissue (Miller et al. 2012). Visual scoring systems to estimate body condition from analysis of aerial photographs (Miller et al. 2012), and amplitude-mode ultrasound in live, free-swimming whales or direct measurements of blubber thickness in dead whales have been performed in SRWs off the coast of South Africa (Miller et al. 2011). In the latter, acoustic measurements of blubber thickness in live whales, including calves, were comparable to measurements of blubber thickness in dead whales (Tormosov et al. 1998, Miller et al. 2011). In all of these investigations and in most mortality reports for SRWs and related NRWs, assessment of body condition has largely been based on blubber thickness, and descriptions of cavitary fat or skeletal muscle abundance or paucity have not been reported (Best et al. 2001, Moore et al. 2005). In our study, a majority of examined SRWs (14 of 20) had histologic evidence of cavitary fat atrophy; however, emaciation was not reported at the time of gross necropsy and has not been reported in live SRWs in any of our annual aerial surveys. A limitation of these data is that they have been based on subjective assessment. To improve upon these assessments, objective criteria to analyze body condition in archived and prospectively captured aerial photographs of live whales are being developed, and quantitative analysis of blubber thickness and lipid analysis of blubber and bone marrow in dead animals are topics of current investigations. Results may help to resolve apparent contradictions between visual assessments and histologic findings and to answer questions about poor body condition as a possible contributing factor in the high number of PV SRW calf deaths.

\section{Kelp gull-whale interactions}

Originally described by Thomas in 1984 (Thomas 1988), a unique parasitic relationship in which kelp gulls prey on the flesh of living whales exists between the gulls and SRWs at PV (Thomas 1988, Rowntree et al. 1998, Sironi et al. 2009, Marón et al. 2015). Because of this, it has been speculated that predisposition to parasitism by gulls might arise in whales with pre-existing skin damage or disease, or that gull peck wounds could lead to systemic bacterial infection and contribute to the high number of deaths in SRW calves (Thomas et al. 2013). For example, poxvirus infection has recently been reported in a single SRW calf (and possibly a second adult) with gull wounds (Fiorito et al. 2015). In our study, cutaneous bacterial or viral infections, including poxvirus, papillomavirus, or CeMV, which might predispose to parasitism, were not identified through histologic examination or PCR. However, ongoing surveillance to identify outbreaks that might be superimposed on the current high mortalities is warranted. Several of our findings also suggest gull-wound-induced septicemia as an unlikely sequela in the deaths of the majority of whales examined to date. These include the relatively superficial nature of lesions in submitted samples and the lack of consistent histologic findings suggestive of systemic inflammation or bacterial sepsis in all but one examined SRW.

Despite the lack of a direct, detectable relationship between gull-inflicted wounds and death in SRWs, our results do not imply that wounds inflicted by gulls or that gull harassment are inconsequential. Similar to what was reported by Marón et al. (2015), our analyses show that calves with gull wounds are longer, and therefore older, than SRW calves without 
gull wounds. Marón and colleagues also showed that the more time a calf spends on the calving grounds, the more numerous and severe are the lesions, and they suggest this could translate into a greater likelihood of suffering negative effects of gull interactions. In addition, Thomas (1988), Rowntree et al. (1998), and Sironi et al. (2009) described significant behavioral impacts in SRWs that are harassed and parasitized by kelp gulls. These include increased time spent swimming at faster speeds and decreased nursing intervals in cow/calf pairs. It is therefore reasonable to suspect that harassment and the production of extensive wounds could result in a complex set of negative factors, behavioral (i.e. increased energetic demands related to avoidance behavior) as well as physiologic (i.e. abnormalities in thermoregulation, dehydration related to decreased suckling, or transdermal fluid loss through extensive open wounds), which could contribute to or cause death in affected animals (Namdar et al. 2010, Thomas et al. 2013). Scientific studies focused on these factors have, to date, not been performed and are currently a priority for the SRWHMP.

\section{CONCLUSION}

High numbers of annual SRW deaths at PV since 2007 (>35 deaths $\mathrm{yr}^{-1}$ ) and the population level impacts resulting from these losses are of great concern (IWC 2011, Cooke 2012, Rowntree et al. 2013, Thomas et al. 2013, Sironi et al. 2014). Through our investigation, a cause or likely cause of death was identified in 14 but not identified in 198 SRWs. Infectious disease or trauma from anthropogenic factors (i.e. ship strike, marine debris entanglement) were not recognized as significant factors in SRWs examined to date, and a specific cause or combination of factors within or across years to explain the majority of deaths or the reason for the high prevalence of deaths in perinates and calves-of-the-year along the coast of PV has not been found. Application of existing and novel technologies for infectious, toxic or nutritional diseases, telemetry studies to answer outstanding questions about SRW migration, assessment of food availability for cows on feeding grounds, development of objective methods for determining maternal and calf fitness and body condition, and physiologic studies to assess the effects of gull harassment and parasitism on SRW health remain as needs for continued study and are topics of active new initiatives. Continued monitoring to identify independent, interrelated or concurrent factors and detection of outbreaks of disease that may overlap with the existing recurrent mortality events will expand our understanding of SRW ecology and health.

Acknowledgements. We are grateful for generous financial support from the Office of Protected Resources of the US National Marine Fisheries Service, National Ocean and Atmospheric Administration (Order Nos. DG133F-02-SE0901, DG-133F-06-SE-5823, and DG133F07SE4651), the US Marine Mammal Commission (Grants E4047315 and E406 1768), the International Whaling Commission, the Island Foundation Inc., the Lawrence Foundation, Fondo para la Conservación Ambiental del Banco Galicia, the Association of Zoo Veterinary Technicians, the University of California, Davis, the Wildlife Conservation Society, and several private individuals. We also acknowledge the significant contributions of the Instituto de Conservación de Ballenas (ICB), Ocean Alliance, Fundación Patagonia Natural, Fundación Ecocentro Puerto Madryn, Armada Argentina, Prefectura Naval Argentina and Aluar, Woods Hole Oceanographic Institution, University of North Carolina Wilmington, and the International Fund for Animal Welfare. Our thanks and heartfelt appreciation are also extended to an extensive network of partners, collaborators, and volunteers, including D. Taboada, R. Schteinbarg, L. Valenzuela, C. Marón, M. Ricciardi, G. and P. Harris, G. Caille, P. de Diego, and the Provincial Park Rangers and Whale Watching captains at Península Valdés, who have contributed their time, energy, and expertise to the Southern Right Whale Health Monitoring Program. Lastly, we also thank R. Brownell, A. Butler, P. Calle, T. Chang, R. Cook, A. Fox, D. Friedman, F. Gulland, W. Karesh, K. Marchese, J. Landolfi, K. Moore, M. Moore, W. McLellan, A. Newton, A. Ngbokoli, J. Rhyan, C. Rodriguez, R. Rosario, H. Rosenbaum, P. Rowe, T. Rowles, K. Terio, P. Thomas, B. Thomsen, K. Trotta, and J. St. Leger for their technical and professional expertise, and H. Rosenbaum and T. Chang and A. Fox, respectively, for the SRW genomic DNA and influenza A positive control samples they so generously provided. Research permits for this work were issued annually by the Dirección de Fauna y Flora Silvestre and the Subsecretaría de Turismo y Áreas Protegidas of Chubut Province, Argentina. Samples were exported from Argentina under appropriate Argentine CITES Export Permits from Secretaria de Ambiente y Desarrollo Sustentable de la Nación and imported into the USA under US CITES Import Permits to the National Marine Fisheries Service, Marine Mammal Health and Stranding Response Program (MMHSRP), and MMHSRP Marine Mammal Protection Act/Endangered Species Act Permits.

\section{LITERATURE CITED}

Arbelo M, Espinosa de los Monteros A, Herráez P, Andrada $M$ and others (2013) Pathology and causes of death of stranded cetaceans in the Canary Islands (1999-2005). Dis Aquat Org 103:87-99

Best P, Ruther H (1992) Aerial photogrammetry of southern right whales, Eubalaena australis. J Zool (Lond) 228: 595-614

Best P, Schell D (1996) Stable isotopes in southern right whale (Eubalaena australis) baleen as indicators of seasonal movements, feeding and growth. Mar Biol 124: 483-494 
Best P, Peddemors V, Cockcroft V, Rice N (2001) Mortalities of right whales and related anthropogenic factors in South African waters, 1963-1998. J Cetacean Res Manag Special Issue 2:171-176

> Bogomolni AL, Pugliares KR, Sharp SM, Patchett K and others (2010) Mortality trends of stranded marine mammals on Cape Cod and southeastern Massachusetts, USA, 2000 to 2006. Dis Aquat Org 88:143-155

- Borsa P (2006) Marine mammal strandings in the New Caledonia region, Southwest Pacific. C R Biol 329:277-288

Bracht AJ, Brudek RL, Ewing RY, Manire CA and others (2006) Genetic identification of novel poxviruses of cetaceans and pinnipeds. Arch Virol 151:423-438

Campbell-Malone R, Barco SG, Daoust P, Knowlton A, McClellan W, Rotstein D, Moore M (2008) Gross and histologic evidence of sharp and blunt trauma in North Atlantic right whales (Eubalaena glacialis) killed by vessels. J Zoo Wildl Med 39:37-55

Cassoff RM, Moore KM, McLellan WA, Barco SG, Rotsteins DS, Moore MJ (2011) Lethal entanglement in baleen whales. Dis Aquat Org 96:175-185

Cooke J (2012) Southwest Atlantic right whales: updated population assessment from photo-ID collected at Península Valdés, Argentina. Document SC/64/Rep1 Annex F, IWC, Cambridge, p 21

Cooke J, Rowntree V, Payne R (2001) Estimates of demographic parameters for southern right whales (Eubalaena australis) observed off Península Valdés, Argentina. J Cetacean Res Manag Special Issue 2:125-132

Cummings W, Fish J, Thompson P (1972) Sound production and other behavior of southern right whales Eubalaena glacialis. Trans San Diego Soc Nat Hist 17:1-14

D'Agostino V, Hoffmeyer M, Degrati M (2015) Faecal analysis of southern right whales (Eubalaena australis) in Península Valdés calving ground, Argentina: Calanus australis, a key prey species. J Mar Biol Assoc UK

Dailey MD, Gulland FM, Lowenstine LJ, Silvagni P, Howard D (2000) Prey, parasites and pathology associated with the mortality of a juvenile gray whale (Eschrichtius robustus) stranded along the northern California coast. Dis Aquat Org 42:111-117

> Davison NJ, Barnett JE, Perrett LL, Dawson CE, Perkins MW, Deaville RC, Jepson PD (2013) Meningoencephalitis and arthritis associated with Brucella ceti in a shortbeaked common dolphin (Delphinus delphis). J Wildl Dis 49:632-636

> Davison NJ, Brownlow A, McGovern B, Dagleish MP and others (2015) First report of Brucella ceti-associated meningoencephalitis in a long-finned pilot whale Globicephala melas. Dis Aquat Org 116:237-241

> de la Riva GT, Kreuder Johnson CK, Gulland FM, Langlois GW, Heyning JE, Rowles TK, Mazet JA (2009) Association of an unusual marine mammal mortality event with Pseudo-nitzschia spp. blooms along the southern California coastline. J Wildl Dis 45:109-121

> Delaney MA, Terio KA, Colegrove KM, Briggs MB, Kinsel MJ (2013) Occlusive fungal tracheitis in 4 captive bottlenose dolphins (Tursiops truncatus). Vet Pathol 50: $172-176$

> Doucette GJ, Cembella AD, Martin JL, Michaud J, Cole TVN, Rolland RM (2006) Paralytic shellfish poisoning (PSP) toxins in North Atlantic right whales Eubalaena glacialis and their zooplankton prey in the Bay of Fundy, Canada. Mar Ecol Prog Ser 306:303-313

> Doucette GJ, Mikulski CM, King KL, Roth PB and others
(2012) Endangered North Atlantic right whales (Eubalaena glacialis) experience repeated, concurrent exposure to multiple environmental neurotoxins produced by marine algae. Environ Res 112:67-76

> Duignan PJ, Geraci JR, Raga JA, Calzada N (1992) Pathology of morbillivirus infection in striped dolphins (Stenella coeruleoalba) from Valencia and Murcia, Spain. Can J Vet Res 56:242-248

- Fernández A, Esperón F, Herraéz P, Espinosa de los Monteros A and others (2008) Morbillivirus and pilot whale deaths, Mediterranean Sea. Emerg Infect Dis 14:792-794

Fiorito C, Palacios C, Golemba M, Bratanich A and others (2015) Identification, molecular and phylogenetic analysis of poxvirus in skin lesions of southern right whale. Dis Aquat Org 116:157-163

Geraci JR, Lounsbury VJ (eds) (2005) Marine mammals ashore: a field guide for strandings, 2nd edn. National Aquarium of Baltimore, Baltimore, MD

Geraci J, Anderson D, Tirnperi R, St. Aubin D, Early G, Prescott J, Mayo C (1989) Humpback whales (Megatpera novaeangliae) fatally poisoned by dinoflagellate toxin. Can J Fish Aquat Sci 46:1895-1898

Gil M, Torres A, Harvey M, Esteves J (2006) Heavy metals in marine organisms from the coastal zone of Continental Argentine Patagonia. Rev Biol Mar Oceanogr 41: $167-176$

Gould S (2007) The respiratory system. In: Keeling J, Khong $\mathrm{T}$ (eds) Fetal and neonatal pathology. Springer, Heidelberg, p 531-570

Greig A, Secchi E, Zerbini A, Rosa L (2001) Stranding events of southern right whales, Eubalaena australis, in southern Brazil. J Cetacean Res Manag Special Issue 2: $157-160$

Groch KR, Marcondes MC, Colosio AC, Catão-Dias JL (2012) Skeletal abnormalities in humpback whales Megaptera novaeangliae stranded in the Brazilian breeding ground. Dis Aquat Org 101:145-158

- Groch KR, Colosio AC, Marcondes MC, Zucca D and others (2014) Novel cetacean morbillivirus in Guiana dolphin, Brazil. Emerg Infect Dis 20:511-513

Gulland F, Pérez-Cortés H, Urbán J, Rojas-Bracho L, Ylitalo G, Weir J, Norman S, Muto M, Rugh D, Kreuder C, Rowles T (2005) Eastern North Pacific gray whale (Eschrichtius robustus) unusual mortality event, 19992000. US Dept Commerce, NOAA Tech Memo. NMFSAFSC-150, NOAA, Seattle, WA

Guzmán-Verri C, González-Barrientos R, Hernández-Mora G, Morales J, Baquero-Calvo E, Chaves-Olarte E, Moreno E (2012) Brucella ceti and brucellosis in cetaceans. Front Cell Infect Microbiol 2:3

Herráez P, Espinosa de los Monteros A, Fernández A, Edwards J, Sacchini S, Sierra E (2013) Capture myopathy in live-stranded cetaceans. Vet J 196:181-188

IWC (International Whaling Commission) (2001) International Whaling Commission: report of the workshop on the comprehensive assessment of right whales: a worldwide comparison. J Cetacean Res Manag Special Issue 2: $1-60$

IWC (2011) International Whaling Commission: report of the IWC workshop on the assessment of southern right whales. Document SC/64/Rep5, IWC, Buenos Aires, p 1-39

IWC (2014) International Whaling Commission: report of the $2^{\text {nd }}$ workshop on mortality of southern right whales (Eubalaena australis) at Península Valdés, Argentina. 
Document SC/66a/Rep 8 IWC, Chubut, p 1-24

> Jauniaux T, Charlier G, Desmecht M, Haelters J and others (2000) Pathological findings in two fin whales (Balaenoptera physalus) with evidence of morbillivirus infection. J Comp Pathol 123:198-201

Knowlton A, Kraus S (2001) Mortality and serious injury of northern right whales (Eubalaena glacialis) in the western North Atlantic Ocean. J Cetacean Res Manag Special Issue 2:193-208

La Sala L, Pozzi L, McAloose D, Kaplan F and others (2012) Severe soft tissue ossification in a southern right whale Eubalaena australis. Dis Aquat Org 102:149-156

- Leaper R, Cooke J, Trathan P, Reid K, Rowntree V, Payne R (2006) Global climate drives southern right whale (Eubalaena australis) population dynamics. Biol Lett 2: 289-292

> Lefebvre KA, Bargu S, Kieckhefer T, Silver MV (2002) From sanddabs to blue whales: the pervasiveness of domoic acid. Toxicon 40:971-977

Lipscomb TP, Schulman FY, Moffett D, Kennedy S (1994) Morbilliviral disease in Atlantic bottlenose dolphins (Tursiops truncatus) from the 1987-1988 epizootic. J Wildl Dis 30:567-571

Marón CF, Beltramino L, Di Martino M, Chirife A and others (2015) Increased wounding of southern right whale (Eubalaena australis) calves by kelp gulls (Larus dominicanus) at Península Valdés, Argentina. PLoS ONE 10: e0139291

Martino J, Wise S, Perkins C, Kerr I, Rowntree V, Sironi M (2012) Metal levels in southern right whale (Eubalaena australis) skin biopsies from Península Valdés, Argentina. Document SC/64/BRG7, IWC, Cambridge

McLellan W, Rommel S, Moore M, Pabst D (2004) Right whale necropsy protocol. Final Report to NOAA Fisheries for contract \#40AANF112525. US Department of Commerce, National Oceanic and Atmospheric Administration, National Marine Fisheries Service, Office of Protected Resources, Silver Spring, MD

Miller C, Reeb D, Best P, Knowlton A, Brown M, Moore M (2011) Blubber thickness in right whales Eubalaena glacialis and Eubalaena australis related with reproduction, life history status and prey abundance. Mar Ecol Prog Ser 438:267-283

Miller C, Best P, Perryman W, Baumgartner M, Moore M (2012) Body shape changes associated with reproductive status, nutritive condition and growth in right whales Eubalaena glacialis and E. australis. Mar Ecol Prog Ser 459:135-156

Miller MA, Grigg ME, Kreuder C, James ER and others (2004) An unusual genotype of Toxoplasma gondii is common in California sea otters (Enhydra lutris nereis) and is a cause of mortality. Int $\mathrm{J}$ Parasitol 34:275-284

Moore M, Knowlton A, Kraus S, McLellan W, Bonde R (2005) Morphometry, gross morphology and available histopathology in North Atlantic right whale (Eubalaena glacialis) mortalities. J Cetacean Res Manag 6:199-214

Morris SE, Zelner JL, Fauquier DA, Rowles TK and others (2015) Partially observed epidemics in wildlife hosts: modelling an outbreak of dolphin morbillivirus in the northwestern Atlantic, June 2013-2014. J R Soc Interface 12:20150676. doi:10.1098/rsif.2015.0676

Namdar T, Stollwerck P, Stang F, Siemers F, Mailänder P, Lange T (2010) Transdermal fluid loss in severely burned patients. Ger Med Sci 8:Doc28

Ohishi K, Takishita K, Kawato M, Zenitani R and others
(2004) Molecular evidence of new variant Brucella in North Pacific common minke whales. Microbes Infect 6: 1199-1204

Panigada S, Pesante G, Zanardelli M, Capoulade F, Gannier A, Weinrich M (2006) Mediterranean fin whales at risk from fatal ship strikes. Mar Pollut Bull 52:1287-1298

Payne R (1986) Long term behavioral studies of the southern right whale (Eubalaena australis). Rep Int Whaling Comm Special Issue 10:161-167

Payne R, Brazier O, Dorsey E, Perkins J, Rowntree V, Titus A (1983) External features in southern right whales (Eubalaena australis) and their use in identifying individuals. AAAS Selected Symposia Series 76, Westview Press, Boulder, CO

Rivarola M, Campagna C, Tagliorette A (2001) Demand-driven commercial whalewatching in Península Valdés (Patagonia): conservation implications for right whales. $\mathrm{J}$ Cetacean Res Manag Special Issue 2:145-151

> Rosas CL, Gil MN, Uhart MM (2012) Trace metal concentrations in southern right whale (Eubalaena australis) at Península Valdés, Argentina. Mar Pollut Bull 64: 1255-1260

> Rowntree V, McGuinness P, Marshall K, Payne R, Sironi M, Seger J (1998) Increased harassment of right whales (Eubalaena australis) by kelp gulls (Larus dominicanus) at Peninsula Valdes, Argentina. Mar Mamm Sci 14:99-115

Rowntree V, Payne R, Schell D (2001) Changing patterns of habitat use by southern right whales (Eubalaena australis) on their calving ground at Península Valdés, Argentina and their long-range movements. J Cetacean Res Manag Special Issue 2:133-143

> Rowntree V, Uhart M, Sironi M, Chirife A and others (2013) Unexplained recurring high mortality of southern right whale Eubalaena australis calves at Península Valdés, Argentina. Mar Ecol Prog Ser 493:275-289

Rubio-Guerri C, Melero M, Esperón F, Bellière E and others (2013) Unusual striped dolphin mass mortality episode related to cetacean morbillivirus in the Spanish Mediterranean Sea. BMC Vet Res 9:106-111

Shumway S, Allen S, Boersma D (2003) Marine birds and harmful algal blooms: sporadic victims or under-reported events? Harmful Algae 2:1-17

Silvagni PA, Lowenstine LJ, Spraker T, Lipscomb TP, Gulland FM (2005) Pathology of domoic acid toxicity in California sea lions (Zalophus californianus). Vet Pathol 42: $184-191$

Sironi M (2004) Behavior and social development of juvenile southern right whales (Euabalaena australis) and interspecific interactions at Península Valdés, Argentina. PhD dissertation, University of Wisconsin, Madison, WI

Sironi M, Rowntree V, Snowdon C, Valenzuela L, Marón C (2009) Kelp gulls (Larus dominicanus) feeding on southern right whales (Eubalaena australis) at Península Valdés, Argentina: updated estimates and conservation implications. Document SC/61/BRG19. IWC, Portugal

Sironi M, Rowntree V, Di Martino M, Beltramino L, Rago V, Franco M, Uhart M (2014) Updated information for 2012-2013 on southern right whale mortalities at Península Valdés, Argentina. Document SC/65b/BRG06, IWC, Bled

> Sledge DG, Bolin SR, Lim A, Kaloustian LL, Heller RL, Carmona FM, Kiupel M (2011) Outbreaks of severe enteric disease associated with Eimeria furonis infection in ferrets (Mustela putorius furo) of 3 densely populated groups. J Am Vet Med Assoc 239:1584-1588 
Spackman E, Senne DA, Bulaga LL, Myers TJ and others (2003) Development of real-time RT-PCR for the detection of avian influenza virus. Avian Dis 47:1079-1082

Stephens N, Duignan P, Wang J, Bingham J and others (2014) Cetacean morbillivirus in coastal Indo-Pacific bottlenose dolphins, Western Australia. Emerg Infect Dis 20: 666-670

Stone BM, Blyde DJ, Saliki JT, Blas-Machado U and others (2011) Fatal cetacean morbillivirus infection in an Australian offshore bottlenose dolphin (Tursiops truncatus). Aust Vet J 89:452-457

Stroud RK, Roffe TJ (1979) Causes of death in marine mammals stranded along the Oregon coast. J Wildl Dis 15: 91-97

Thomas P (1988) Kelp gulls, Larus dominicanus, are parasites on flesh of the right whale, Eubalaena australis. Ethology 79:89-103

Thomas P, Taber S (1984) Mother-infant interaction and behavioral development in southern right whales, Eubalaena australis. Behaviour 88:42-60

Thomas P, Uhart M, McAloose D, Sironi M and others (2013) Workshop on the southern right whale die-off at Península Valdés, Argentina. Document SC/65/BRG15, IWC, Cambridge

Tormosov D, Mikhaliev Y, Best PB, Zemsky V, Sekiguchi K, Brownell R (1998) Soviet catches of southern right whales Eubalaena australis, 1951-1971. Biological data and conservation implications. Biol Conserv 86: 185-197

Torres P, Miglioranza K, Uhart M, Gonzalez M, Commendatore $M$ (2015) Organochlorine pesticides and PCBs in southern right whales (Eubalaena australis) breeding at Península Valdés, Argentina. Sci Total Environ 518-519: 605-615

Uhart M, Rowntree V, Mohamed N, Pozzi L and others (2008) Strandings of southern right whales (Eubalaena australis) at Península Valdés, Argentina from 2003. Document SC/60/BRG15, IWC, Cambridge

Uhart M, Rowntree V, Sironi M, Chirife A and others (2009) Continuing southern right whale mortality events at Península Valdés, Argentina. Document SC/61/BRG18, IWC, Cambridge

Editorial responsibility: Michael Moore, Woods Hole, Massachusetts, USA
Valenzuela LO, Sironi M, Rowntree VJ, Seger J (2009) Isotopic and genetic evidence for culturally inherited site fidelity to feeding grounds in southern right whales (Eubalaena australis). Mol Ecol 18:782-791

Van Bressem M, Van Waerebeek K, Jepson P, Antonio J and others (2001) An insight into the epidemiology of dolphin morbillivirus worldwide. Vet Microbiol 81:287-304

- Van Bressem MF, Raga JA, Di Guardo G, Jepson PD and others (2009) Emerging infectious diseases in cetaceans worldwide and the possible role of environmental stressors. Dis Aquat Org 86:143-157

> Van Bressem MF, Duignan PJ, Banyard A, Barbieri M and others (2014) Cetacean morbillivirus: current knowledge and future directions. Viruses 6:5145-5181

> Venn-Watson S, Benham C, Gulland F, Smith C and others (2012) Clinical relevance of novel Otarine herpesvirus-3 in California sea lions (Zalophus californianus): lymphoma, esophageal ulcers, and strandings. Vet Res 43:85

Venn-Watson S, Colegrove K, Litz J, Kinsel M and others (2015) Adrenal gland and lung lesions in Gulf of Mexico common bottlenose dolphins (Tursiops truncatus) found dead following the deepwater horizon oil spill. PLoS One 10:e0126538

West K, Sanchez S, Rotstein D, Robertson K and others (2013) A Longman's beaked whale (Indopacetus pacificus) strands in Maui, Hawaii, with first case of morbillivirus in the central Pacific. Mar Mamm Sci 29:767-776

> West KL, Levine G, Jacob J, Jensen B, Sanchez S, Colegrove K, Rotstein D (2015) Coinfection and vertical transmission of Brucella and morbillivirus in a neonatal sperm whale (Physeter macrocephalus) in Hawaii, USA. J Wildl Dis 51:227-232

> Wilson C, Sastre A, Hoffmeyer M, Rowntree V and others (2015) Southern right whale (Eubalaena australis) calf mortality at Península Valdés, Argentina: Are harmful algal blooms to blame? Mar Mamm Sci, doi:10.1111/ mms.12263

> Zabka TS, Goldstein T, Cross C, Mueller RW, Kreuder-Johnson C, Gill S, Gulland FM (2009) Characterization of a degenerative cardiomyopathy associated with domoic acid toxicity in California sea lions (Zalophus californianus). Vet Pathol 46:105-119

Submitted: February 26, 2015; Accepted: February 25, 2016 Proofs received from author(s): March 25, 2016 